\title{
Control of cortical neuronal migration by glutamate and GABA
}

\author{
Heiko J. Luhmann ${ }^{1}$ *, A. Fukuda ${ }^{2}$ and W. Kilb ${ }^{1}$ \\ ${ }^{1}$ Institute of Physiology, University Medical Center of the Johannes Gutenberg University, Mainz, Germany \\ ${ }^{2}$ Department of Neurophysiology, Hamamatsu University School of Medicine, Hamamatsu, Shizuoka, Japan
}

\section{Edited by:}

Takeshi Kawauchi, Keio University

School of Medicine/PRESTO, Japan

\section{Reviewed by:}

Rustem Khazipov, Institut National de la Santé et de la Recherche Médicale, France

Laura Cancedda, Istituto Italiano di Tecnologia, Italy

\section{*Correspondence:}

Heiko J. Luhmann, Institute of Physiology, University Medical Center of the Johannes Gutenberg

University, Duesbergweg 6,

D-55128 Mainz, Germany

e-mail: luhmann@uni-mainz.de
Neuronal migration in the cortex is controlled by the paracrine action of the classical neurotransmitters glutamate and GABA. Glutamate controls radial migration of pyramidal neurons by acting primarily on NMDA receptors and regulates tangential migration of inhibitory interneurons by activating non-NMDA and NMDA receptors. GABA, acting on ionotropic $\mathrm{GABA}_{A}$-rho and $\mathrm{GABA}_{A}$ receptors, has a dichotomic action on radially migrating neurons by acting as a GO signal in lower layers and as a STOP signal in upper cortical plate $(C P)$, respectively. Metabotropic $G A B A_{B}$ receptors promote radial migration into the $\mathrm{CP}$ and tangential migration of interneurons. Besides GABA, the endogenous GABAergic agonist taurine is a relevant agonist controlling radial migration. To a smaller extent glycine receptor activation can also influence radial and tangential migration. Activation of glutamate and GABA receptors causes increases in intracellular $\mathrm{Ca}^{2+}$ transients, which promote neuronal migration by acting on the cytoskeleton. Pharmacological or genetic manipulation of glutamate or GABA receptors during early corticogenesis induce heterotopic cell clusters in upper layers and loss of cortical lamination, i.e., neuronal migration disorders which can be associated with neurological or neuropsychiatric diseases. The pivotal role of NMDA and ionotropic GABA receptors in cortical neuronal migration is of major clinical relevance, since a number of drugs acting on these receptors (e.g., anti-epileptics, anesthetics, alcohol) may disturb the normal migration pattern when present during early corticogenesis.

Keywords: neuronal migration, cerebral cortex, GABA, glutamate, neuronal migration disorders

\section{INTRODUCTION}

During early brain development, mostly during embryonic phases and in some species also during early postnatal periods, newly generated neurons must migrate from their site of origin to their final target in a distinct brain area and a certain subregion, e.g., a specific layer at a certain site of the cerebral cortex. The distances that neurons must travel depend on the cell type and on the species and range from a few hundred micrometers to many millimeters. One exciting question in neuroscience is how newly generated neurons find their correct way to their final position. Over the last two decades we learned that the neuronal migration process is controlled by a number of different mechanisms. Transcription factors control the identity and the laminar position of developing neurons (for review, Kwan et al., 2012). Chemical cues, e.g., semaphorines and ephrins, are expressed as gradients in the brain and serve as attracting or repelling signals for migrating cells (Bagnard et al., 2001; Holmberg et al., 2006; Zimmer et al., 2008; Sentürk et al., 2011). In some brain regions the vertical fibers of radial glial cells act as chemico-mechanical guiding structures for migrating neurons (for review, Huang, 2009). Receptors activated by neurotransmitters or certain molecules, e.g., the extracellular matrix protein reelin, act as GO or STOP signals in neuronal migration (Huang, 2009).
This review will focus on the role of the two classical neurotransmitter systems glutamate and GABA in neuronal migration of cortical neurons. After briefly describing the different modes of neuronal migration and differences in the migration process between glutamatergic and GABAergic neurons, our current knowledge on the function of glutamate and GABA receptors in neuronal migration will be reviewed. Finally, we will also shortly address the putative role of glycine receptors in neuronal migration. Since the receptors of both transmitters are the target of numerous drugs acting for example as anesthetics or anti-epileptics, pathophysiological perturbations of the migration process by unwanted side effects of these drugs acting on glutamate and GABA receptors during early brain development will be also discussed.

For comprehensive overviews on the molecular and cellular mechanisms of neuronal migration the interested reader is referred to reviews by Ayala et al. (2007), Valiente and Marín (2010) and the review by David. J. Price on "Neuronal migration in the cerebral cortex" in this issue. A summary on neocortical layer formation, the timing of projection and interneuron migration and a comparison between rats and mice is given in the reviews by Kwan et al. (2012) and Tanaka and Nakajima (2012). An update on the early development of the human cerebral cortex is given by Bystron et al. (2008). 


\section{MODES OF NEURONAL MIGRATION}

Different modes of neuronal migration have been described (Figure 1). In 1972, Pasko Rakic published a seminal paper on the "Mode of cell migration to the superficial layers of fetal monkey neocortex" and described the radial migration of immature neocortical neurons along the vertical fibers of radial glial cells (Rakic, 1972). Rakic postulated the existence of a "strong surface affinity" between the radial glial fibers and the migrating neuron and suggested that this "developmental mechanism ... would allow for the vertical cell columns of adult neocortex" (Rakic, 1972). The radial unit hypothesis of the cerebral cortex was born. The radial glia-dependent locomotion is the dominant migration mode of newborn pyramidal, glutamatergic neurons in the hippocampus and cerebral cortex and also represents the central mechanism for the "inside first-outside last" developmental pattern of the cerebral cortex (neurons marked in red in Figure 1B; Nadarajah et al., 2003). Like building a house, the oldest neurons form the lowest layer 6 and subsequently generated neurons form layers 5, 4, 3 and finally layer 2. This inside-out layering also means that radially migrating neurons must pass beyond their predecessors before reaching their final position in the newly generated cortical layer, which they form (for review, Cooper, 2008). Recently Le Magueresse et al. (2012) described with time-lapse 2-photon microscopy in acute brain slice preparations of the neonatal mouse a new type of radial migration of subventricular zone (SVZ)-generated neurons along astrocytes lining blood vessels, which does not depend on radial glial cells.

A different mode of neuronal migration, which is independent of glial guiding fibers, is the somal translocation (Nadarajah et al., 2003; for review, Cooper, 2008). Somal translocation is smoother and faster than glia-guided radial migration. Here a leading coiled process extends into the marginal zone (MZ) and is anchored to the basement membrane or to the extracellular matrix. The soma moves upward in a spring-like manner by rapidly shortening the leading process. It seems likely that gliaindependent somal translocation and glia-dependent locomotion depend on different cytoskeletal machinery and motors and thereby are regulated by different processes.

In contrast to the radial migration of pyramidal cells, neocortical GABAergic interneurons show a tangential migration pattern throughout the developing telencephalon (de Carlos et al., 1996; for review, Marín, 2013). Inhibitory interneurons migrate tangentially over long distances by generating a leading process, which detects chemical cues in the extracellular environment, and subsequent movement of the nucleus towards to the branching point (nucleokinesis). Recent observations in slice cultures of the mouse embryonic brain indicate that endothelial cells may guide tangential migration (Won et al., 2013) and that tangential migration in the MZ is controlled by meningeal vessels (Borrell and Marín, 2006). The molecular mechanism of this blood vessel-guided migration to the cortex are not known, but neurotrophic factors such as brainderived neurotrophic factor (BDNF) and glial cell line-derived neurotrophic factor (GDNF) may be involved (Le Magueresse et al., 2012). Meninges affect tangential migration in the MZ via secretion of the chemokine CXCL12 which activates CXCR4 receptors (Borrell and Marín, 2006). This type of migration may become reactivated in the adult brain under pathophysiological conditions, e.g., stroke, when SVZ-generated neuroblasts are guided to the peri-infarct zone by blood vessels (Kojima et al., 2010).

Finally, so-called random walk migration has been described for medial ganglionic eminence (MGE)-derived cortical interneurons in the MZ of flat-mount cortices (Tanaka et al., 2009). Interneurons migrated tangentially over periods of up to
A

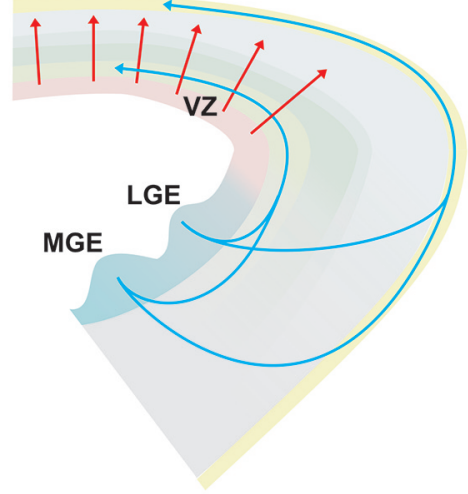

B

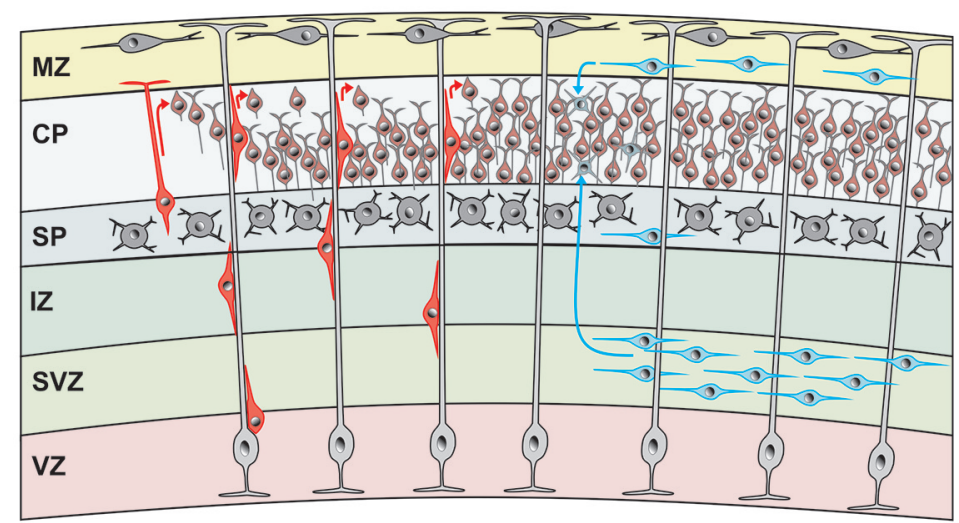

FIGURE 1 | Origin and migratory pathways of glutamatergic and GABAergic neurons. (A) Schematic diagram illustrating migration pathway of the majority of glutamatergic neurons, originating in the ventricular zone (VZ) of the pallium and radially migrating into the developing cerebral cortex (red arrows). The majority of GABAergic neurons are generated in the medial (MGE) and lateral gangionic eminence (LGE) and reach their final position by tangential migration via deep pathways and superficial cortical layers. (B) Glutamatergic neurons (marked in different shades of red) are generated in the VZ and migrate radially either by somal translocation or, at later phases, by locomotion along radial glial cells (light gray). Upon reaching the marginal zone (MZ) they detach and align on top of previously generated neurons of the cortical plate (CP), generating the "inside first-outside last" pattern of the cerebral cortex. The majority of GABAergic neurons (marked in different shades of blue) reach the cortex via tangential migration in the deep pathway within the subventricular zone (SVZ) or the superficial pathway in the MZ Some GABAergic interneurons travel also within the subplate (SP). 
2 days in an unpredictable manner, often changing the rate and direction of migration. These results suggest that MGE-derived cortical interneurons, once arriving at the $\mathrm{MZ}$, are released from regulation by guidance cues and initiate random walk movement (Tanaka et al., 2009).

In summary, radial migration, somal translocation and tangential migration are the dominant forms of neuronal migration in the developing cerebral cortex. It is not surprising that mutations affecting genes, which control these forms of migration may cause severe brain malformations, which are generally categorized as neuronal migration disorders and which are often associated with a spectrum of neurological and/or neuropsychiatric diseases (for review, Guerrini et al., 2008; Guerrini and Parrini, 2010).

\section{MIGRATION OF GLUTAMATERGIC NEURONS}

Neocortical glutamatergic neurons mostly follow a pure radial migration pattern and for them radial glial cells in the ventricular zone (VZ) fulfill two important and different functions in the embryonic cortex (Figure 1). On the one hand radial glial cells serve as progenitors and produce by asymmetric cell division neurons and astrocytes, on the other hand radial glial cells serve as migratory guides for the newly generated glutamatergic neurons. Radial glial cells produces neocortical pyramidal and layer 4 spiny stellate cells, which migrate to the cortical plate (CP), thereby forming in the "inside firstoutside last" pattern the usually six-layered cerebral cortex. Sister glutamatergic neurons, which derive from the same mother cell, take up radially aligned positions in the cerebral cortex across layers and have a higher propensity to form unidirectional chemical synaptic connections with each other rather than with neighboring non-siblings (Yu et al., 2009). These data indicate that the columnar organization of the cerebral cortex may be determined to some extent by lineage (Noctor et al., 2001).

During early embryonic development, these glutamatergic neurons initially use somal translocation to migrate radially and then follow the vertical track along radial glial fibers for locomotion (Rakic, 1972). The extracellular matrix protein reelin, which is secreted from early born Cajal-Retzius neurons located in the MZ (for review, Kirischuk et al., 2014), controls this radial migration (for review, Valiente and Marín, 2010). Radial migration of single glutamatergic neurons does not occur continuously following a straightforward route, but rather shows phases of transient migratory arrest and even retrograde migration (Noctor et al., 2004). Gap junctions play important roles in the regulation of both proliferation and neuronal migration. Hemichannels formed by gap junctions mediate the spread of spontaneous intracellular $\mathrm{Ca}^{2+}$ waves across progenitor cells and provide dynamic adhesive contacts between migrating neurons and radial glial fibers (for review, Elias and Kriegstein, 2008). For glia-guided neuronal migration the connexins $\mathrm{Cx} 26$ and $\mathrm{Cx} 43$ are essential and in the mouse their deletion disrupts migration to the CP (Elias et al., 2007). For Cx43 it has been demonstrated that deletion of the C-terminal domain modifies neuronal migration (Cina et al., 2009).
Recent immunohistochemical data obtained in embryonic mice demonstrated one population of transient glutamatergic neurons, which is generated early (at embryonic day (E) 12.5) and migrates tangentially over long distances from their generation site at the pallial-subpallial boundary to the CP (Teissier et al., 2010). At birth, these early glutamatergic neurons homogeneously populate all neocortical areas, but subsequently die massively by apoptosis. At birth, about 50\% of the dying neocortical neurons belong to this population of tangential migrating glutamatergic neurons (Teissier et al., 2010).

In summary, glutamatergic neurons use mostly radial migration along radial glial fibers and somal translocation to move from their site of generation in the $\mathrm{VZ}$ into the developing cerebral cortex.

\section{MIGRATION OF GABAergic NEURONS}

In contrast to the large majority of the glutamatergic neurons, cortical GABAergic interneurons are at least in rodents generated in the subcortical telencephalon; in the lateral, medial, caudal and septal ganglionic eminence (LGE, MGE, CGE, and SGE, respectively; Figure $\mathbf{1 A}$ ), to a minor extent also in the endopeduncular and preoptic area and also in the cortical SVZ (for review, Gelman and Marin, 2010) see also review by Wieland B. Huttner on "Neurogenesis in the developing cerebral cortex" in this issue. A subset of GABAergic neurons, which are $5-\mathrm{HT}_{3}$ positive, are generated postnatally in the SVZ and migrate into numerous forebrain regions, including the cerebral cortex, striatum, and nucleus accumbens (Inta et al., 2008). The origin of GABAergic neocortical interneurons in higher mammals, including humans, remains controversial, although a recent publication indicate that also in these species a substantial proportion of interneurons originate from subcortical telencephalic eminences (Letinic et al., 2002; Ma et al., 2013).

The spatio-temporal expression of various transcription factors control the generation and identity of different types of cortical GABAergic interneurons at different developmental periods (for review, Butt et al., 2007; Jovanovic and Thomson, 2011). Dlx1/2 and Mash1 are extensively expressed in the ganglionic eminence and determine the GABAergic lineage. Lhx6, which is under the control of $N k \times 2.1$ and Dlx5/6, control the generation of parvalbumin- and somatostatinimmunoreactive interneurons, which are generated first in the ventral and dorsal area of the MGE, respectively (Wang et al., 2010). The later generation of vasoactive intestinal polypeptide (VIP) and cholecystokinine (CCK) expressing GABAergic interneurons in the CGE is controlled by the transcription factors $N k x 6.2$ and CoupTF1/2. The spatio-temporal developmental profile of cortical GABAergic interneurons predicts their intrinsic electrophysiological properties and firing patterns in the mature cortex (Butt et al., 2005). Rapidly adapting firing properties can be observed in mature neuropeptide Y (NPY), reelin, calretinin and/or vasointestinal peptide expressing cortical interneurons, which are generated in the CGE. Rapidly adapting NPY-containing interneurons are also produced in the preoptic area (for review, Marín, 2013). 
From their birth place in the ganglionic eminence forebrain GABAergic interneurons migrate tangentially in the MZ, SVZ or intermediate zone (IZ) to the developing cerebral cortex (for review, Marín, 2013). Tangential migration is controlled by the spatio-temporal expression of a number of chemical cues, acting as attracting or repelling signals. Semaphorines, expressed in the LGE, prevent the entry of migrating interneurons into this region and Ephrin EphA5/EphA4 receptors, expressed in the VZ, repel MGE-generated interneurons (for review, Marín, 2013). Tangential migration of cortical GABAergic interneurons is enhanced by the neurotrophic factors BDNF, NT-4, hepatocyte growth factor, and GDNF. On their way to the cortex, interneurons use specific routes or migratory streams (marked in blue in Figure 1B): (i) a superficial route in the MZ; (ii) a deep route in the IZ/SVZ; and (iii) a route in the subplate (SP). Using an in situ migration assay, Tanaka et al. (2003) observed that neocortical GABAergic interneurons initially migrate predominantly in the IZ/SVZ and then invade the $\mathrm{CP}$ and $\mathrm{MZ}$ by departing from the major migratory stream in the IZ/SVZ. Once arriving in the MZ GABAergic interneurons show random walk migration and disperse throughout the cortex (Tanaka et al., 2009). A subpopulation of GABAergic interneurons descend from the $\mathrm{MZ}$ to be distributed in the CP.

During their tangential migration process, neocortical GABAergic interneurons progressively acquire responsiveness to GABA. Combining in vitro patch-clamp recordings, neuropharmacological experiments and single-cell PCR in E14.5 mouse acute slices, Carlson and Yeh (2011) characterized the functional expression of $\mathrm{GABA}_{\mathrm{A}}$ receptor subunits in tangentially migrating interneurons derived from the MGE. At this age, synapses have not yet formed and responsiveness to GABA reflect the functional expression of synaptic and extrasynaptic $\mathrm{GABA}_{\mathrm{A}}$ receptors. Early migrating interneurons located close to the corticostriate juncture showed a robust expression of the alpha 2 and alpha3 subunits. When entering the developing cortex, both subunits were still highly expressed and in addition alphal and gamma1-3 subunits were upregulated (Carlson and Yeh, 2011). The functional implications of the simultaneous activation of multiple $\mathrm{GABA}_{\mathrm{A}}$ receptor isoforms and the upregulation of receptor isoforms with higher affinity to GABA in the migration process are not known and need to be elucidated.

Some experimental data indicate that migrating interneurons on their way to the cortex may move from one substrate to another, e.g., following specific axonal projections. Once they have reached their final cortical region, cortical GABAergic interneurons migrate radially to their final layer, which has been already formed by the radial migration of glutamatergic neurons. Thus, GABAergic interneurons invade their target layers after glutamatergic projection neurons have reached their final position. The mechanisms underlying this switch from tangential to radial migration are not completely understood. It may be that an intrinsic developmental program or connexins trigger the tangential-to-radial switch (for review, Marín, 2013). Elias et al. (2010) have demonstrated in embryonic rat brain slices including the MGE that this switch is controlled by
Cx43 and depends on the adhesive properties and the $\mathrm{C}$ terminus of $\mathrm{Cx} 43$, but not on the $\mathrm{Cx} 43$ channel. These data indicate that the switch from tangential to radial migration depends on a gap junction-mediated interaction between migrating GABAergic interneurons and radial glia cells, similarly to the glia-dependent migration of glutamatergic neurons. In contrast, whereas reelin signaling is essential for proper radial migration of pyramidal neurons, layer acquisition of neocortical GABAergic interneurons does not depend on reelin, but rather on cues provided by projection neurons (Pla et al., 2006).

In summary, GABAergic interneurons migrate tangentially along specific streams from their site of origin in the subcortical telencephalon to their final neocortical site, where they then migrate radially to their final cortical layer.

\section{ROLE OF GLUTAMATE IN NEURONAL MIGRATION}

The classical excitatory transmitter glutamate influences neuronal migration mainly by acting on two ionotropic receptors: (i) the NMDA receptor, a $\mathrm{Ca}^{2+}$-permeable subclass of glutamate receptor; (ii) the AMPA/kainate receptor, a usually $\mathrm{Ca}^{2+}$ impermeable glutamate receptor. Three (GluR1-3) of the four known subunits for AMPA receptors are expressed at prenatal stages in the developing cortex, while the GluR4 subunit appears only postnatally (Luján et al., 2005). Of the four subunits assembling kainate receptors, KA-2 and GluR5 and GluR6 are already expressed in the embryonic neocortex around E14 (Bahn et al., 1994). Functional NMDA receptors are composed from two NR1 and two NR2 subunits. NR1 and the highly $\mathrm{Ca}^{2+}$ permeable NR2B subunits are already expressed at early postnatal stages, while expression of NR2A emerges at postnatal stages in the neocortex (Luján et al., 2005). Functional NMDA receptors have been found on migrating glutamatergic and GABAergic interneurons (Behar et al., 1999; Soria and Valdeolmillos, 2002). Metabotropic glutamate receptors, in particular mGlul and mGlu5, are also already expressed in the immature neocortex (LópezBendito et al., 2002a). A direct modulation of neuronal migration by NMDA receptors has been initially described by Komuro and Rakic for granule cells of the developing mouse cerebellum in vitro. Here, blockade of NMDA receptors by specific antagonists caused a slow-down of neuronal migration, whereas enhanced activation of NMDA receptors by removal of magnesium from the extracellular milieu or by application of the cotransmitter glycine accelerated cell movement (Komuro and Rakic, 1993).

Various in vitro studies using different models of cortical neuronal migration indicate that NMDA receptors also control radial neuronal migration in the cerebral cortex. In cell dissociates of murine embryonic cortical cells and cortical slice cultures, Behar et al. (1999) demonstrated that glutamate is a potent chemoattractant. Only activation of NMDA receptors, but not other ionotropic glutamate receptors, stimulated radial migration of immature neurons out of the cortical VZ/SVZ and application of NMDA antagonists blocked migration (Figure 2B; Behar et al., 1999). Inhibition of NMDA receptors using either MK801 or $\mathrm{APV}$, attenuated radial migration in rat tissue explants in vitro 


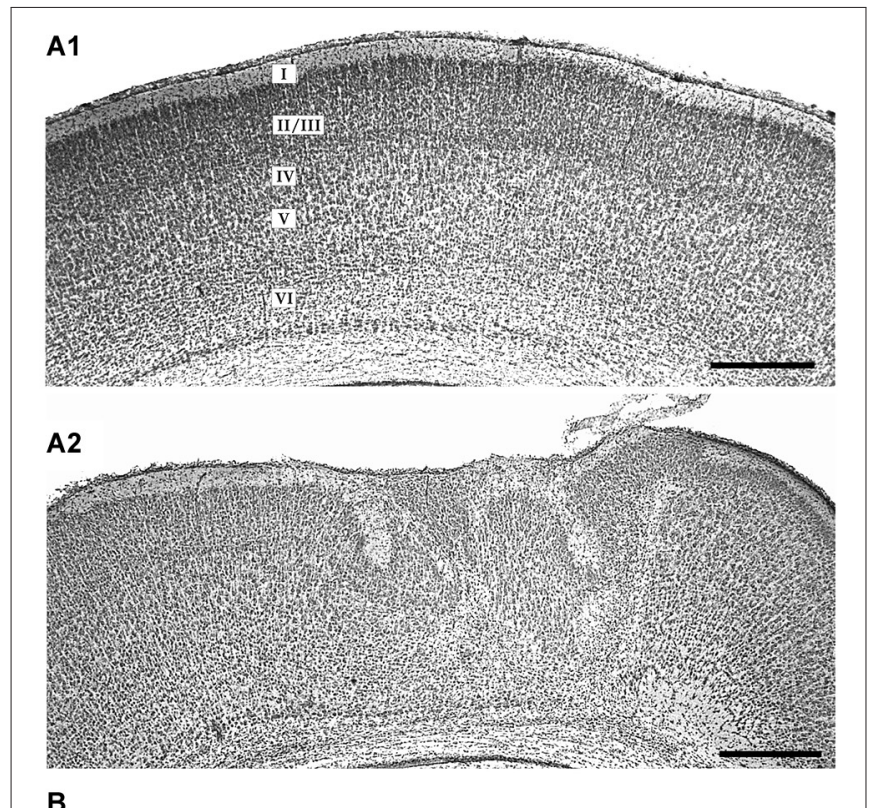

B

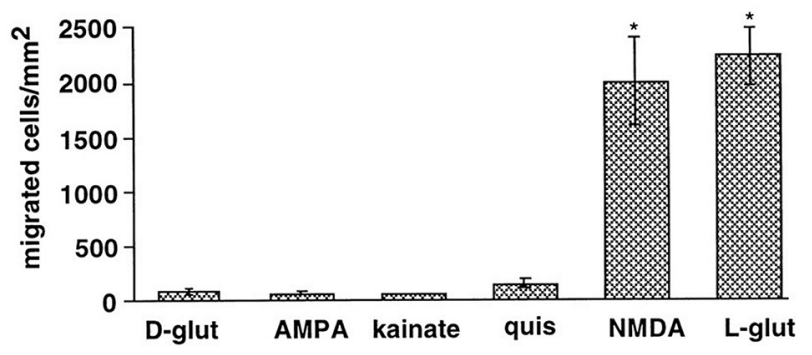

FIGURE 2 | Role of ionotropic glutamate receptors on radial migration in vivo and in vitro. (A) Digital photographs of Nissl-stained coronal sections from a P7 rat that received at P0 on the cortical surface an Elvax implant containing DMSO (A1, control) or an implant loaded with the NMDA antagonist MK801 (A2). Note abnormal cortical architecture and heterotopia in upper layers of the MK801-treated rat. (B) NMDA receptors mediate glutamate-induced migration of dissociated embryonic cortical cells in vitro. Reproduced with permission from Reiprich et al. (2005) (A) and Behar et al. (1999) (B). Scale bars in (A) correspond to $500 \mu \mathrm{m}$.

(Hirai et al., 1999). In contrast to these observations, which suggest a promigratory effect of NMDA receptors, a massive stimulation of NMDA receptors led to migratory arrest in cultured cerebral neurons (Kihara et al., 2002), indicating that only physiological levels of NMDA receptor activation may be a prerequisite for a promigratory stimulus. The observations that (i) $\mathrm{Mg}^{2+}$ depletion enhances migration (Behar et al., 1999); (ii) overexpression of the $\mathrm{Mg}^{2+}$-sensitive NR2B subunit increases migration (Tárnok et al., 2008); and (iii) the NR2B subtype specific antagonist ifenprodil hinder migration of cerebellar neurons (Mancini and Atchison, 2007), all indicate that $\mathrm{Mg}^{2+}$ sensitive NMDA receptors are involved in regulating neuronal migration. It has been also suggested that depolarized membrane potentials of migrating neurons contribute to the relative $\mathrm{Mg}^{2+}$ insensitivity of the NMDA receptor-mediated effects (Gerber et al., 2010).

Also in tangentially migrating neocortical interneurons an inhibition of NMDA and AMPA receptors impedes migration
(Bortone and Polleux, 2009), in accordance with the functional expression of NMDA and non-NMDA ionotropic glutamate receptors in migrating interneurons (Soria and Valdeolmillos, 2002). Unfortunately this study does not allow to discriminate whether AMPA and/or NMDA receptors affect migration. However, at least for mouse hippocampal interneurons it has been demonstrated that AMPA, but not NMDA receptors, influence radial migration (Manent et al., 2006). Therefore further analysis whether AMPA receptors are involved in the tangential migration of neocortical interneurons is required to elucidate if this is a common feature of interneuronal tangential migration.

In neurospheres it has been demonstrated that the early phases of neural progenitor cell migration strictly depend on AMPA receptors (Jansson et al., 2013). However, it is currently unclear whether AMPA receptors also contribute early phases of radial and/or tangential neuronal migration under in vivo conditions.

Further evidences for a role of glutamate in migration of neocortical neurons came from in vivo studies. Using intracerebral injections of ibotenate, an agonist of NMDA receptors and glutamatergic metabotropic receptors, Marret et al. (1996) demonstrated in the hamster by neuropharmacological experiments that activation of NMDA receptors caused a wide spectrum of abnormal neuronal migration patterns in the cerebral cortex in vivo. Golden hamsters were chosen for these studies because compared to mice and rats the cortex in hamsters is very immature at birth. While low doses of ibotenate produced mainly intracortical heterotopias and molecular layer ectopias, indicating an disturbed termination of migration, high ibotenate doses led mainly to periventricular and subcortical heterotopias, suggesting that they affected migratory onset (Marret et al., 1996). These migration defects could be attributed to both migration arrest and unsufficient termination of migration (Takano et al., 2004). Using sustained-release polymer Elvax implants (Smith et al., 1995) containing MK801 to deliver this NMDA antagonist focally to the cortical surface, Reiprich et al. (2005) could demonstrate that a local and transient NMDA receptor blockade in the somatosensory cortex of newborn rats in vivo produces structural and functional alterations in the cortical region underlying the implant (Figure 2A). MK801-treated animals showed disturbances in the cortical lamination and heterotopic cell clusters in the upper layers.

Complete knockout of NR1, an essential subunit of NMDA receptors, has no effect on the early migration pattern of neocortical neurons in the fetal mouse brain, but mice die at birth due to respiratory problems (Messersmith et al., 1997). A restricted knockout of NR1 in excitatory neocortical neurons (CxNR1KO) led to only slight changes in the neocortical organization, like a disordered barrel cortex, without gross anatomical disturbances reminiscent of cortical migration disorders (Iwasato et al., 2000), but in these animals residual amounts of functional NMDA receptors may be present during prenatal development. The function of NR1 in neuronal migration may be also compensated by other mechanisms in CxNR1KO. On the other hand, in chimeric mice transfected with NR1-deficient stem cells, neurons without functional NMDA receptors show 
a normal distribution within the hippocampus, indicating that NMDA receptors on neuronal membranes itself may be dispensable for correct radial migration (Maskos and McKay, 2003).

Thus no final conclusion on the role of NMDA receptors for migration can currently be given. While pharmacological in vivo and in vitro experiments strongly suggest an important role of NMDA receptors for radial migration, the observation that neurons lacking functional NMDA receptors show adequate migration questions this conclusion. These conflicting results may either indicate that the NMDA receptor dependent effects are mediated by non-neuronal target structures like glial cells or that compensatory mechanisms may counteract the lack of functional NMDA receptors.

The source of extracellular glutamate controlling neuronal migration is not completely known. In vitro studies on hippocampal organotypic slice co-culture assays from munc18-1 knockout mice, in which vesicular transmitter release is deleted, indicate that glutamate and also GABA is released in a SNAREindependent manner and both transmitters control neuronal migration via a paracrine action (Manent et al., 2005). Another mechanism of extracellular transmitter control are transporters. Glutamate uptake by transporters expressed in astrocytes set extracellular glutamate levels. The expression of glutamate transporters is relatively low in immature rodent hippocampus and increases during early postnatal development (Thomas et al., 2011), suggesting that extracellular concentrations of glutamate may be higher during early corticogenesis when neuronal migration occurs. However, extracellular space is also larger during early development (for review, Syková, 2004), therefore overall extracellular transmitter concentrations in the young brain may be not so much higher than in adult. Furthermore, inhibition of glutamate uptake enhances migration (Komuro and Rakic, 1993), which indicates that glutamate is sequestered rather than released in the vicinity of migration neurons. Related to the glutamatergic system, it has been demonstrated in the cerebellum that glutamate activates Bergmann glial cells to produce and release d-serine, which potentiates glutamate actions on NMDA receptors and enhances neuronal migration of cerebellar granule neurons (Kim et al., 2005).

The downstream molecular mechanisms how glutamate controls neuronal migration are not completely understood, but an appropriate increase in the intracellular $\mathrm{Ca}^{2+}$ level is pivotal (for review, Komuro and Kumada, 2005; Zheng and Poo, 2007). Elegant experiments performed on migrating cerebellar neurons in vitro demonstrated that migratory and resting phases were directly correlated to elevated and resting $\mathrm{Ca}^{2+}$ concentrations, respectively (Figure 3; Komuro and Rakic, 1996). In addition, this study demonstrates that the amplitude of $\mathrm{Ca}^{2+}$ transients is directly correlated to the rate of saltatory cell movements. Disappearance of these $\mathrm{Ca}^{2+}$ transients triggered the completion of cerebellar granule cell migration (Kumada and Komuro, 2004). In an interesting experiment Fahrion et al. (2012) were able to rescue methylmercury-induced migratory arrest of murine cerebellar neurons by restoring the frequency of $\mathrm{Ca}^{2+}$ transients to control levels. Further support for a pivotal role of intracellular $\mathrm{Ca}^{2+}$ in controlling neuronal migration comes from

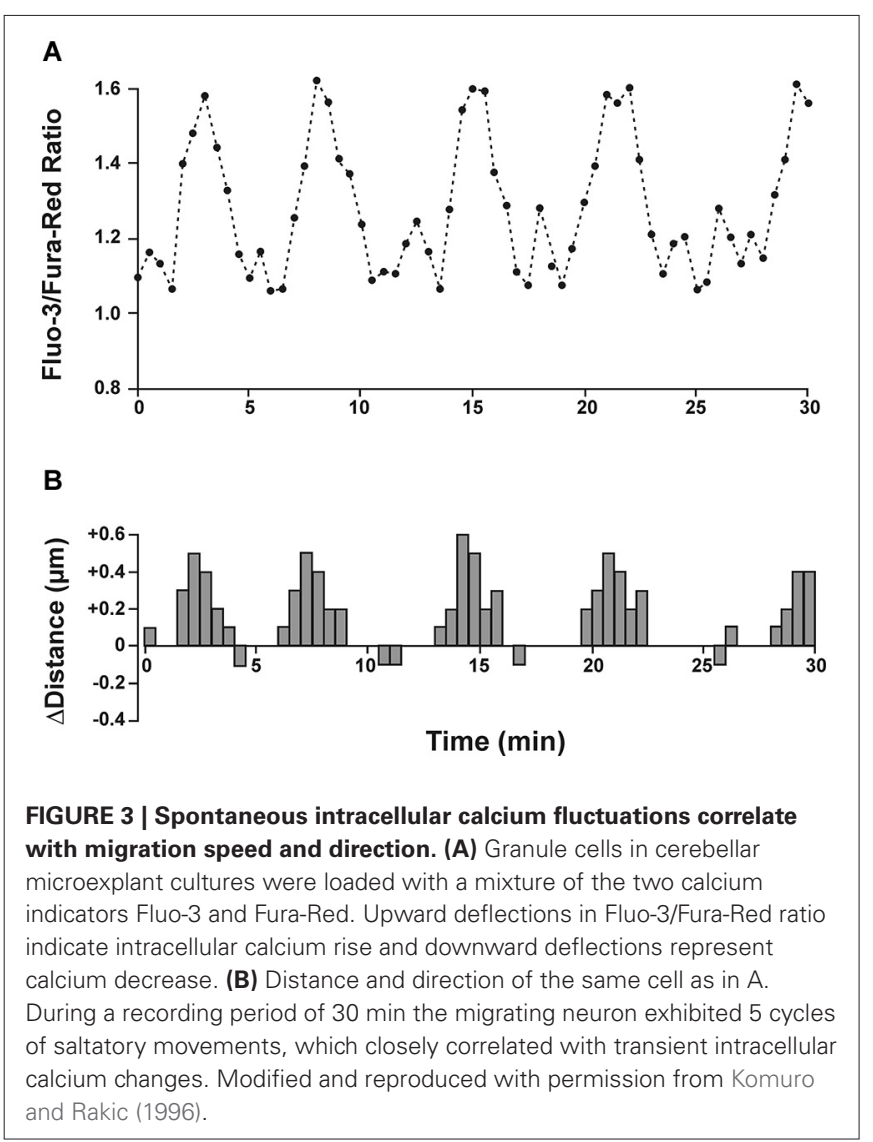

experiments in which the $\mathrm{Ca}^{2+}$ chelator BAPTA inhibited radial migration in murine cerebellar (Komuro and Rakic, 1993) and murine neocortical cells (Hirai et al., 1999). Interestingly, soma translocation in migrating GABAergic interneurons depend on the occurrence of non-symmetrical $\mathrm{Ca}^{2+}$ signals, with larger $\mathrm{Ca}^{2+}$ transients observed toward the direction of migration (Moya and Valdeolmillos, 2004). On the other hand, a tonic $\mathrm{Ca}^{2+}$ increase arrested motility in the absence of $\mathrm{Ca}^{2+}$ transients (Komuro and Rakic, 1996). These data demonstrate that fluctuations in the intracellular $\mathrm{Ca}^{2+}$ concentration within a physiological range control normal neuronal migration.

The $\mathrm{Ca}^{2+}$ transients can interfere with the organization of the cytoskeleton via an activation of $\mathrm{Ca}^{2+}$ dependent kinases, like $\mathrm{Ca}^{2+}$-calmodulin kinases II or doublecortin (DCX)-like kinases (Kumada and Komuro, 2004; Koizumi et al., 2006). Accordingly, inactivation of either DCX or the DCX-like kinase by shRNA slowed radial and tangential neuronal migration (Friocourt et al., 2007, see also review by Fiona Francis on "The roles of DCX in cortical development" in this issue). In addition, a $\mathrm{Ca}^{2+}$ increase also activates Lis1-dependet rho-kinases, which are involved in connecting the microtubules in a Clip170 dependent manner to the actin cytoskeleton and dynein motor complexes (Kholmanskikh et al., 2006, see also review by Emilie Pacary on "Role of RhoGTPases in cerebral cortex development" in this issue). Interestingly, mutations in Lis1 and DCX have been directly linked to human neocortical migration disorders (Gleeson and Walsh, 2000). 
In summary, there is compelling evidence that glutamate controls radial migration of glutamatergic neurons, most probably by acting on NMDA receptors. The mechanisms of the glutamate effect on tangential migration of GABAergic interneurons is less established and here AMPA receptors are more relevant.

\section{ROLE OF GABA AND TAURINE IN NEURONAL MIGRATION}

The classical inhibitory neurotransmitter GABA is important in controlling neuronal migration via ionotropic $\mathrm{GABA}_{\mathrm{A}}$ and metabotropic $\mathrm{GABA}_{B}$ receptors (Manent and Represa, 2007). $\mathrm{GABA}_{\mathrm{A}}$ receptors are heteropentamers compiled from in total 19 subunits, divided into eight groups, while $\mathrm{GABA}_{\mathrm{B}}$ receptors are heterodimers co-assembled from the $\mathrm{GABA}_{\mathrm{B} 2}$ subunit with one of the two isoforms of the GABA $\mathrm{B}_{1}$ subunit (for a detailed review, see Farrant and Kaila, 2007; Ulrich and Bettler, 2007). Several GABA receptor subunits are abundantly expressed during early cortical development. At E14 the $\mathrm{GABA}_{\mathrm{A}}$ receptor subunits $\alpha_{2}, \alpha_{3}, \alpha_{4}, \beta_{1}$ and $\gamma_{1}$ are expressed, with $\alpha_{3}$ expressed at particular high levels during prenatal development (Laurie et al., 1992). Accordingly, GABA A $_{\text {A }}$ receptor mediated currents are observed already in proliferative neuroblasts and early postmitotic neurons (LoTurco et al., 1995; Owens et al., 1999). In line with the paucity of $\alpha_{1}$ and $\gamma_{2}$ expression, immature cortical neurons show $\mathrm{GABA}_{\mathrm{A}}$ receptor mediated currents with slow kinetics and little desensitization, high GABA affinity and lack of synaptic GABAergic currents before they terminate migration in the CP (Owens et al., 1999). In addition to this classical $\mathrm{GABA}_{\mathrm{A}}$ receptor, $\rho$ subunit containing $\mathrm{GABA}_{\mathrm{A}}$-rho receptors, characterized by an exceptionally high GABA affinity and little desensitization, are found in the SVZ, while they are lacking in $\mathrm{CP}$ neurons (Denter et al., 2010). GABA $\mathrm{B}_{1}$ and $\mathrm{GABA}_{\mathrm{B} 2}$ subunits are expressed throughout all neocortical lamia during early stages of cortical development (López-Bendito et al., 2002b). Interestingly tangentially migrating neurons express only $\mathrm{GABA}_{\mathrm{B} 1}$ subunits and should thus lack functional $\mathrm{GABA}_{\mathrm{B}}$ receptors (López-Bendito et al., 2002b). Finally, it is important to consider that immature neocortical neurons show a high ratio in the expression of NKCC1 to $\mathrm{KCC} 2$, which renders $\mathrm{GABA}_{\mathrm{A}}$ mediated responses depolarizing (Yamada et al., 2004).

The implication of GABA receptors in the control of neuronal migration was first demonstrated by Behar et al. (1996), who could show by the use of a microchemotaxis chamber that neuronal migration of dissociated cortical neurons of embryonic rats is stimulated by low concentrations of GABA acting on $\mathrm{GABA}_{\mathrm{A}} / \mathrm{GABA}_{\mathrm{A}}$-rho and $\mathrm{GABA}_{\mathrm{B}}$ receptors. Femtomolar concentrations of GABA induced chemotaxis (migration along a chemical gradient) and micromolar GABA initiated chemokinesis (increased random movement). In a subsequent study Behar et al. (1998) showed that 1-5 $\mu \mathrm{M}$ GABA stimulated the migration of GAD-expressing neurons in the $\mathrm{CP}$, whereas $500 \mathrm{fM}$ stimulated motility of GAD-expressing neurons in the VZ. In this study the authors also postulate that GABA can promote migration via $\mathrm{G}$-protein activation, mediated by $\mathrm{GABA}_{\mathrm{B}}$ receptors, and arrest migration via $\mathrm{GABA}_{\mathrm{A}}$ receptor-mediated depolarization (Behar et al., 1998). Using organotypic neocortical slice cultures Behar et al. demonstrated that specific activation of the different
GABA receptors modified different parts of neural migration to the CP (Behar et al., 2000): (i) $\mathrm{GABA}_{\mathrm{A}} / \mathrm{GABA}_{\mathrm{A}}$-rho receptor activation promoted neuronal migration from the VZ/SVZ to the IZ; (ii) $G_{A B A}$ receptor controlled the migration from the IZ into the $\mathrm{CP}$; and finally (iii) $\mathrm{GABA}_{\mathrm{A}}$ receptor activation provided the stop signal to terminate migration in the upper $\mathrm{CP}$ (Behar et al., 2000). The two ionotropic GABA receptor subtypes, $\mathrm{GABA}_{\mathrm{A}}$ and $\mathrm{GABA}_{\mathrm{A}}$-rho receptors, play different roles in the control of radial migration (Figure $4 \mathrm{~A}$ ). In organotypic murine neocortical slice cultures application of bicuculline methiodide (BMI) facilitated neuronal migration, while the $\mathrm{GABA}_{\mathrm{A}}$-rho specific antagonist TPMPA attenuated migration (Denter et al., 2010). These data add important information to the model on the role of GABA in neuronal migration as initially introduced by Behar et al. (2000). GABA -rho receptors have a high affinity to $\mathrm{GABA}$ and are transiently expressed on migrating neurons in the IZ, where the extracellular GABA concentration at late embryonic stages is relatively low (Figure 4A). In the IZ, GABA acting primarily on $\mathrm{GABA}_{\mathrm{A}}$-rho receptors acts as a GO signal for migrating neurons coming from the VZ/SVZ and passing through the IZ to the CP. Reaching the CP, migrating neurons no longer express functional $\mathrm{GABA}_{\mathrm{A}}$-rho receptors. Due to the intracortical outside directed GABA gradient lowaffinity $\mathrm{GABA}_{\mathrm{A}}$ receptors are now activated and GABA serves as a STOP signal in the upper CP (Denter et al., 2010). Although this model is supported by a number of experimental studies, data on the existence of the outside directed GABA gradient are scare. Regional differences in the amplitudes of $\mathrm{GABA}_{\mathrm{A}}$ receptor-mediated tonic currents suggest a gradient of endogenous $\mathrm{GABA}_{\mathrm{A}}$ receptor agonists in embryonic murine cortex (Furukawa et al., 2014). However, detailed information about spatial gradients in extracellular GABA concentrations are currently not available (Bolteus et al., 2005). GABA imaging in brain slices using immobilized enzyme-linked photoanalysis may provide a possibility to demonstrate such a gradient (Morishima et al., 2010).

Blockade of $\mathrm{GABA}_{\mathrm{B}}$ receptors in organotypic cultures of the rat brain led to an accumulation of tangentially migrating neurons in the VZ/SVZ of the rat neocortex (López-Bendito et al., 2003), suggesting a role of $\mathrm{GABA}_{\mathrm{B}}$ receptors for final apposition of GABAergic interneurons. However since no functional $G_{A B A}$ receptors are expressed on these neurons (López-Bendito et al., $2002 \mathrm{~b}$ ), this effect may be caused by $\mathrm{GABA}_{\mathrm{B}}$ receptor-dependent effect on targets upstream from the migration tangential neurons itself (López-Bendito et al., 2002b).

A direct influence of GABA on the migration of cortical neurons has also be shown in vivo. Furukawa et al. (2014) demonstrated in vivo that continuous blockade of $\mathrm{GABA}_{\mathrm{A}}$ receptors with the $\mathrm{GABA}_{\mathrm{A}}$ antagonist gabazine (SR95531) during late embryonic stages accelerated radial migration in the murine neocortex (Figure 4B). In line with this, Elvax implants loaded with the $\mathrm{GABA}_{\mathrm{A}}$ antagonist $\mathrm{BMI}$ or the agonist muscimol placed on the neocortical surface of newborn rats induced heterotopic cell clusters in upper layers and a loss of neocortical lamination, probably because of an overmigration from the loss of a stop signal (Figure 4C). Whereas BMI caused this effect by blocking $\mathrm{GABA}_{\mathrm{A}}$ receptors, long-term application of muscimol induced 

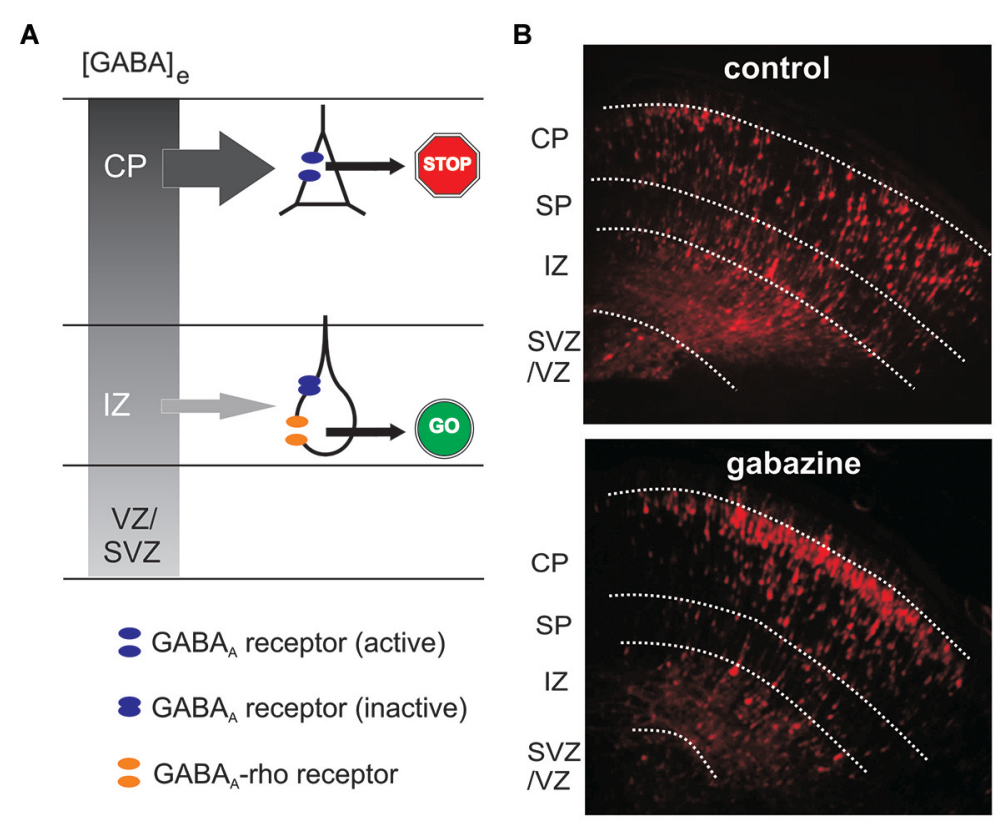

C

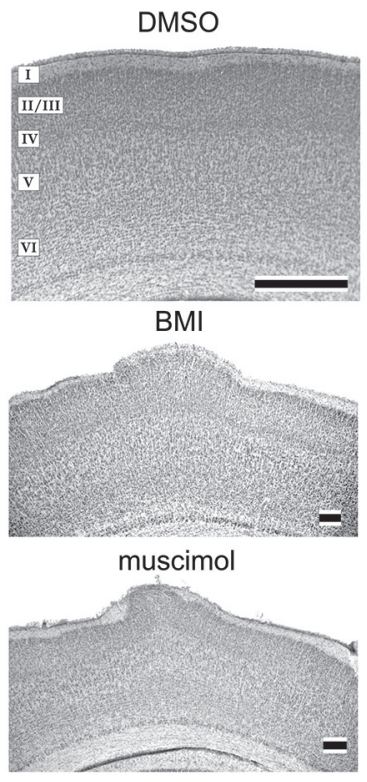

FIGURE 4 | Role of ionotropic GABA receptors on radial migration.

(A) Model of $G A B A_{A}$ and $G A B A_{A}$-rho receptor dependent radial migration in the neonatal cerebral cortex, which shows outside directed GABA gradient (gray colored gradient). In the IZ migrating neurons express functional $G A B A_{A}$ receptors (blue discs) and $\mathrm{GABA}_{A}$-rho receptors (orange discs), whereas in the $\mathrm{CP}$ migrating neurons express only functional $G_{A B A_{A}}$ receptors. Due to the outside directed GABA gradient the low-affinity $\mathrm{GABA}_{A}$ receptors are only activated in the $C P$, while the lower GABA concentration in the $I Z$ is sufficient to activate the high affinity $\mathrm{GABA}_{A}$-rho receptors. Activation of $G A B A_{A}$-rho receptors is necessary to support migration in the $I Z$ (GO sign), while activation of $\mathrm{GABA}_{\mathrm{A}}$ receptors contributes to termination of migration (STOP sign). (B) Blockade of GABA receptors with gabazine facilitates radial migration. Figures illustrate red fluorescent protein (RFP)-positive cells in control (left) and gabazine-treated (right) GAD67 GFP/GFP fetuses at E17.5, which were injected with gabazine at E14.5 immediately after the electroporation of the RFP vectors. (C) Digital photographs of Nissl-stained coronal sections from a P7 rat that received at P0 on the cortical surface an Elvax implant containing DMSO (top, control), the $\mathrm{GABA}_{A}$ antagonist bicuculline methiodide (middle, BMI) or the $\mathrm{GABA}_{A}$ agonist muscimol (bottom). Note upper layer heterotopia due to increased radial migration in BMI- and muscimol-treated animals. Scale bar in B, C middle and $C$ bottom corresponds to $200 \mu \mathrm{m}$, in $C$ top to $500 \mu \mathrm{m}$. Modified with permission from Denter et al. (2010) (A), Furukawa et al. (2014) (B), and Heck et al. (2007) (C). a pronounced receptor desensitization, thereby also reducing $\mathrm{GABA}_{\mathrm{A}}$ receptor function on migrating rat neurons (Heck et al., 2007). In accordance with the results of in vitro studies identifying the role of $\mathrm{GABA}_{\mathrm{B}}$ receptors (Behar et al., 2001), in utero knockdown of $\mathrm{GABA}_{\mathrm{B}}$ receptors using RNA interference techniques impaired radial migration of the affected pyramidal neuron progenitors in the rat neocortex (Bony et al., 2013). The superficial stream of tangentially migrating GABAergic interneurons in the $\mathrm{MZ}$ of neonatal mice is also impaired after inhibition of $\mathrm{GABA}_{\mathrm{A}}$ receptors in vivo (Inada et al., 2011), demonstrating a direct influence of endogenous GABA also on tangential migration.

In summary, these reports demonstrate that ionotropic $\mathrm{GABA}_{\mathrm{A}}$ and metabotropic $\mathrm{GABA}_{\mathrm{B}}$ receptors are involved in the control of neuronal migration in the cortex.

One feature of the GABA receptors expressed on migrating neurons is their high GABA affinity, allowing them to sense even low ambient GABA concentrations. Microdialysis experiments in tangential neocortical slices revealed an extracellular GABA concentration of $25 \mathrm{nmol} / \mathrm{l}$ in the MZ of early postnatal rats (Qian et al., 2014), however, this experimental paradigm may underestimate the interstitial GABA concentration close to migrating neurons. Using GABAergic modulation of glutamate release Dvorzhak et al. (2010) suggested a juxtasynaptic GABA concentration of $250 \mathrm{nmol} / \mathrm{l}$ during early postnatal stages in the mouse, with a substantial developmental decrease during the first postnatal week. A substantially higher ambient GABA concentration of $\sim 0.5 \mu \mathrm{mol} / \mathrm{l}$ was observed in the ganglionic eminence of mice using $\mathrm{GABA}_{\mathrm{A}}$ receptor expressing sniffer cells as GABA sensors (Cuzon et al., 2006), which may be relevant for the tangential migration of GABAergic interneurons from this region.

It was suggested that tangentially migrating GABAergic neurons are a source for GABA (Manent et al., 2005). In vitro assays indicated that $\mathrm{CP}$ neurons itself secrete promigratory signals acting on GABA receptors and suggested that these signals may include GABA and/or taurine (Behar et al., 2001). In line with this, tangentially migrating neurons in GAD67-GFP knockin mice had a substantially slower migration rate, which has been attributed to the lower extracellular GABA level in these animals (Inada et al., 2011). However, no obvious disorders in gross neocortical organization have been observed after complete blockade of GABA synthesis in GAD65/GAD67 knockout mice (Ji et al., 1999), indicating that other substances can act as GABAergic agonists during prenatal development. 
A recent study identified taurine, released by volume-sensitive anion channels, as an important agonist of $\mathrm{GABA}_{\mathrm{A}}$ receptors directly influencing radial migration and its action was most apparent in the SP where taurine is most abundant (Figure 5). A decrease in ambient taurine, via pharmacological blockade of taurine synthesis, accelerated radial migration in the developing cerebral cortex. This effect was clearly mediated via $\mathrm{GABA}_{\mathrm{A}}$ receptors and is more substantial in GAD67 deficient mice with reduced extracellular GABA levels (Furukawa et al., 2014). Thus ambient GABA is not negligible, although ambient taurine is a main endogenous agonist. In addition, it was recently shown that taurine inhibits KCC-2 activity via activating the with-no-lysine protein kinase 1 (WNK1) and downstream STE20/SPS1-related proline/alanine-rich kinase (SPAK)/oxidative stress response 1 (OSR1) signaling pathway (Inoue et al., 2012). Thereby it may also play a role in maintaining the depolarizing GABAergic responses required for a promigratory action (see below). Microdialysis experiments in the MZ of early postnatal rats revealed a taurine concentration of $33 \mu \mathrm{mol} / \mathrm{l}$, which was substantially higher than the GABA concentration (Qian et al., 2014). Thus taurine must also be considered as an important endogenous agonist influencing migration via GABA receptors.

Various mechanisms of GABA release at early stages of corticogenesis have been suggested. GABAergic precursor cells may release GABA tonically in a $\mathrm{Ca}^{2+}$ - and SNARE-independent manner. Blocking $\mathrm{GABA}_{\mathrm{A}}$ receptors in hippocampal slice cultures from munc18-1-deficient mice, in which vesicular release is abolished, impairs neuronal migration, which supports the hypothesis that GABA is released in a non-canonical, paracrine manner (Manent et al., 2005). Candidates for a non-vesicular GABA release are GABA transporters (GATs), which take up GABA from the interstitial space. Whereas in the adult brain GAT-1 is mainly expressed in neurons and GAT-3 mainly in glial cells, in the immature cortex both GAT isoforms are expressed in astrocytes and neurons (for review, Kilb et al., 2013) and both transporters can release GABA by acting in reverse mode (for review, Kirischuk and Kilb, 2012). A nonvesicular release of GABA via reversal of GAT-1 has been demonstrated in tangentially migrating interneurons following glutamate induced activation of AMPA receptors and sodium influx (Poluch and König, 2002). In the MZ, GATs represent the major mechanism of GABA release and their operating mode is influenced by excitatory amino acid transporters (EAATs) via intracellular sodium signaling and/or cell depolarization (Unichenko et al., 2013), indicating that ambient glutamate and GABA levels are mutually dependent. As an alternative mechanism of GABA release, GABA could also be released via anion channels such as bestrophin-1 channel (Lee et al., 2010). However, no direct evidence of GABA release via volumesensitive anion channels has yet been reported. In contrast, a recent study identified taurine, released by volume-sensitive anion channels, as an important agonist of $\mathrm{GABA}_{\mathrm{A}}$ receptors (Figure 5; Furukawa et al., 2014).

In summary, non-synaptic release of GABA and taurine most probably is the main source of ambient GABAergic agonists that influence neuronal migration. However, the contribution

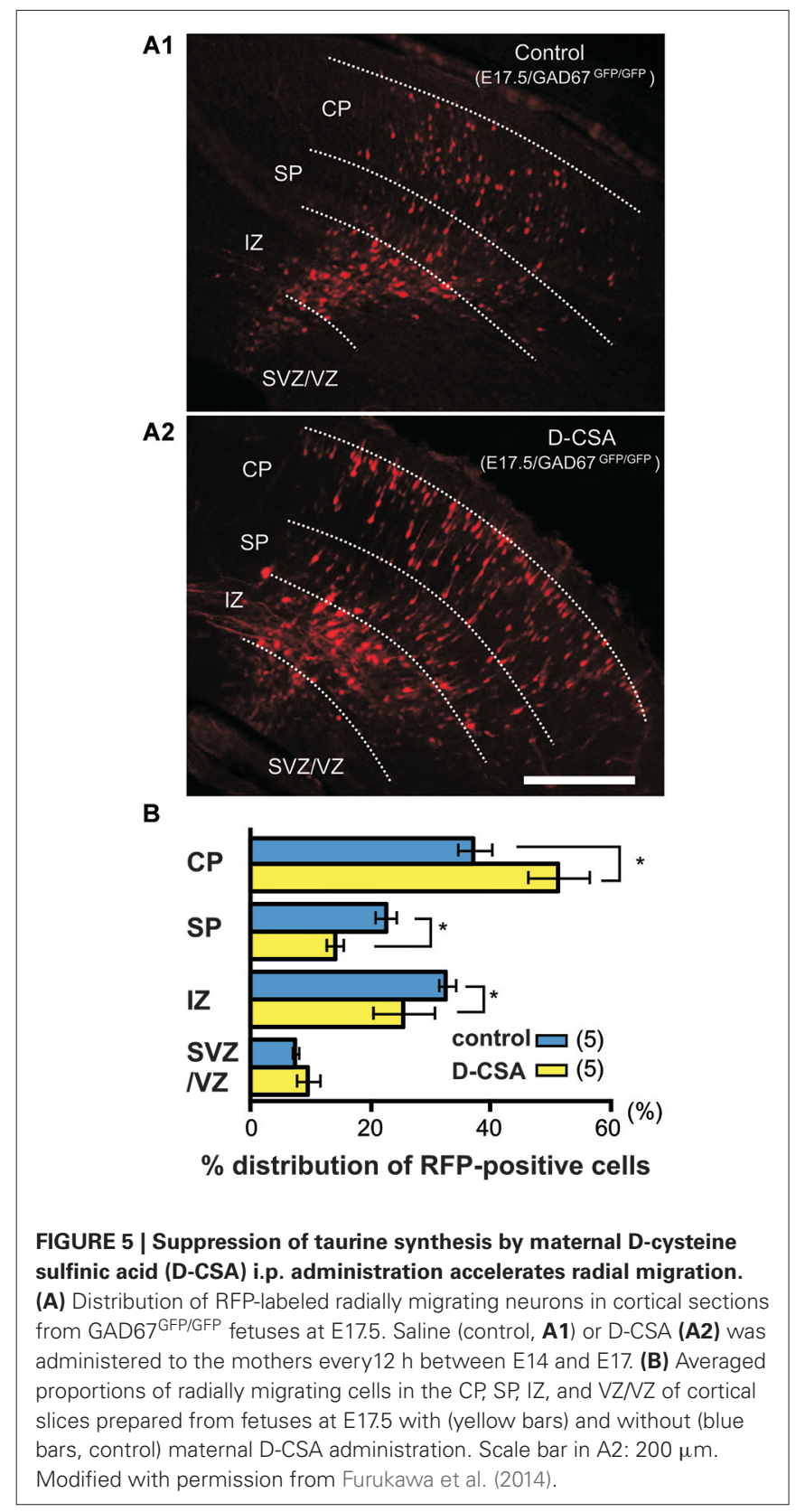

of different release mechanisms for GABA and taurine to their ambient levels have not been determined.

The down-stream pathways of migration control by GABA and taurine are not fully understood. As for glutamate, GABAinduced intracellular $\mathrm{Ca}^{2+}$ transients are essential. Impairing $\mathrm{GABA}_{\mathrm{A}}$ receptor dependent $\mathrm{Ca}^{2+}$ signals by $\mathrm{Ca}^{2+}$ chelators inhibits the chemotropic effect of GABA in cortical cells (Behar et al., 1996) and impedes tangential migration (Inada et al., 2011). These GABA induced $\mathrm{Ca}^{2+}$ transients are mediated by developmental changes in the expression of chloride transporters, leading to depolarizing GABAergic responses (for review, Ben-Ari et al., 2007; Kilb, 2012; Kaila, 2014; Luhmann et al., 2014). Whereas the chloride inward transporter NKCC1 is highly expressed in immature neurons, the efficacy of the 
chloride outward transporter KCC2 is low, and this imbalance in chloride transport causes a high intracellular concentration of chloride ions (Yamada et al., 2004). In accordance with this hypothesis, a pharmacological blockade of NKCC1 using bumetanide impairs tangential migration of murine GABAergic interneurons in vivo (Inada et al., 2011). This hypothesis was challenged by the observation, that premature expression of KCC2 by in utero expression at E17/18 causes no obvious migration deficits of rat neocortical neurons, while causing a hyperpolarizing shift in the chloride reversal potential of GABAinduced currents at early postnatal stages (Cancedda et al., 2007). This result is not too surprising, because ectopically expressed wild type KCC2 is not active in embryonic cerebral cortices and becomes functional only postnatally (Inoue et al., 2012). In addition, the in utero expression was performed at relatively late stages, so that a substantial part of radial migration to layer II/III was already accomplished until E21 (Cancedda et al., 2007). Indeed, ectopic expression of constitutive active KCC2 mutant at E15 lowered intracellular chloride concentrations, rendered hyperpolarizing $\mathrm{GABA}_{\mathrm{A}}$ receptor mediated responses in postmitotic neurons and perturbed their radial migration (Inoue et al., 2012). In migrating murine interneurons the chloride outward transporter KCC2 increases in expression and becomes functional after they enter the cerebral cortex (Bortone and Polleux, 2009), resulting in a reduced intracellular chloride concentration. The consequent shift in GABAergic action from excitation to inhibition leads to a decrease in the frequency of spontaneous intracellular $\mathrm{Ca}^{2+}$ transients and terminates neuronal migration, thus turning GABA into a STOP signal for migrating interneurons (Bortone and Polleux, 2009). This scenario is supported by experimental data from Inoue et al. as mentioned above (Inoue et al., 2012).

In addition to a direct excitatory effect, depolarizing GABAergic responses are also involved in spontaneous activity patterns observed in neocortical networks during pre- and early postnatal development (for review, Khazipov and Luhmann, 2006; Allene and Cossart, 2010; Kilb et al., 2011). In a rat neocortical culture model de Lima et al. (2009) demonstrated a relationship between the expression of spontaneous synchronous network activity and neuronal migration. Although migrating interneurons did not participate in early cortical network activity, migration was terminated when interneurons became active in a synchronous network. These data indicate that synchronized GABA and also glutamate release during early network activity can terminate neuronal migration (de Lima et al., 2009).

In summary, GABA and the endogenous GABAergic agonist taurine have a strong impact on tangential and radial migration. These neurotransmitters have both, promigratory and migrationterminating actions, depending on the type of GABA receptor and the intracellular chloride concentration in the migrating neuron.

\section{ROLE OF GLYCINE IN NEURONAL MIGRATION}

Beside ionotropic GABA receptors, glycine receptors also have an influence on neuronal migration. As $\mathrm{GABA}_{\mathrm{A}}$ and $\mathrm{GABA}_{\mathrm{A}}$-rho receptors, glycine receptors are also transmittergated chloride channels, which upon activation by glycine or taurine mediate a depolarizing or even excitatory action in the immature cortex (Flint et al., 1998; Kilb et al., 2002, 2008). A functional expression of heteromeric glycine receptors, compiled from $\alpha 2 / \beta$ subunits, has already been described in various types of immature neurons, including putative migratory neurons in the IZ (Flint et al., 1998; Kilb et al., 2002, 2008; Okabe et al., 2004), whereas tangentially migrating neurons express $\alpha 2$ homomeric glycine receptors (Avila et al., 2013). It is therefore not surprising that an activation of glycine receptors also promoted radial neuronal migration as demonstrated in organotypic slice cultures from embryonic mouse cerebral cortex (Nimmervoll et al., 2011). However, as pharmacological inhibition of glycine receptors did not interfere with radial migration, Nimmervoll et al. (2011) suggest that glycine receptors do not contribute substantially to radial migration in the neocortex (see also Furukawa et al., 2014). In contrast, tangential migration of cortical interneurons was effectively attenuated by genetic or pharmacological suppression of glycine receptor function in organotypic slice cultures from mouse cortex (Avila et al., 2013). In this study, the migration speed was not affected by addition of taurine, suggesting that glycine itself acts as endogenous neurotransmitter. In line with this suggestion, the estimated extracellular glycine levels of $\sim 150 \mathrm{nmol} / \mathrm{l}$ (Qian et al., 2014) would allow a partial activation of $\alpha 2$ subunit containing receptors with their $\mathrm{EC}_{50}$ of $\sim 0.5 \mu \mathrm{mol} / \mathrm{l}$ (Flint et al., 1998; Okabe et al., 2004), while the estimated extracellular taurine concentration of $33 \mu \mathrm{mol} / \mathrm{l}$ (Qian et al., 2014) is most probably ineffective to activate glycine receptors $\left(\mathrm{EC}_{50}\right.$ for taurine $\sim 2.5 \mathrm{mM}$, Okabe et al., 2004).

In summary, these results indicate that glycine receptors can affect neuronal migration, although these receptors may be relevant only for tangential migration.

\section{ROLE OF GLUTAMATE AND GABA IN NEURONAL MIGRATION DISORDERS}

Given the pivotal role of glutamate and GABA in controlling neuronal migration in the developing cortex, it is not surprising that any modulation in the function of these neurotransmitters during pre- and early postnatal periods may have profound effects on the generation of the cortical architecture. Since neuronal migration is indirectly also controlled by spontaneous network activity, modulation of these transmitter systems may also cause disturbances in early neuronal activity patterns subsequently leading to migration deficits (for review, Kilb et al., 2011).

A direct role of GABA for migration disorders has recently been demonstrated in experimentally induced polymicrogyria. Wang et al. (2014) observed that the accumulation of neurons in the polymicrogyria forming below a neocortical freeze lesion was prevented by the administration of $\mathrm{GABA}_{\mathrm{A}}$ receptor antagonists in vivo. An altered migration caused by excitatory $\mathrm{GABA}_{\mathrm{A}}$ receptors has also been revealed as a cause for the hippocampal granule cell ectopia observed after febrile seizures (Koyama et al., 2012).

A number of drugs, which are taken by pregnant women for control of psychiatric or neurological disorders (e.g., epilepsy), 
anesthetics required for surgical operation of pregnant women, or drug abuse (e.g., ethanol consumption during pregnancy) may have profound effects on neuronal migration patterns in the cortex of the unborn child. These drugs often act on glutamate and/or GABA receptors and, when reaching the immature brain, may change the migration pattern of cortical pyramidal cells and GABA interneurons. Anti-epileptic drugs have a wide range of actions (for review Ikonomidou and Turski, 2010): (i) increasing GABAergic action by inhibiting degradation or uptake mechanisms of GABA; (ii) potentiating GABAergic function by acting on $\mathrm{GABA}_{\mathrm{A}}$ receptor subtypes; (iii) reducing presynaptic glutamate release; (iv) inhibiting glutamate receptor function; and (v) modulating neuronal activity by inhibiting voltage-gated sodium and $\mathrm{Ca}^{2+}$ channels. The most potent anti-epileptic drugs are often unspecific and act via several of these mechanisms. In experimental studies, anti-epileptic drugs were administered in clinically relevant doses to pregnant rats during the last week of gestation (for review, Manent et al., 2011). Prenatal exposure to the antiepileptic drugs vigabatrin and valproate, which both increase extracellular GABA levels, induced neuronal migration disorders in the hippocampus and cerebral cortex (Manent et al., 2007). In line with this, the benzodiazepine diazepam, which augments the activation of $\mathrm{GABA}_{\mathrm{A}}$ receptors, substantially increased the motility rate of migrating GABAergic interneurons (Inada et al., 2011). In contrast the anticonvulsant carbamazepine, which mainly acts on voltage-dependent sodium channels and has only minor effects on GABA receptor function, did not cause major disturbances in neuronal migration (Manent et al., 2007). These data indicate that changes in the extracellular concentration of GABA have a stronger influence on neuronal migration than modifications in spontaneous neuronal activity.

Alcohol exposure during pregnancy is one of the leading causes of mental retardation and several neuroanatomical malformations, including migration disorders such as lissencephaly and cortical heterotopias (for review, Miller, 1992). Ethanol is a drug acting on ionotropic GABA receptors (for review, Lobo and Harris, 2008) and NMDA receptors (for review, Chandrasekar, 2013), which both are key players in the control of neuronal migration. Clinically relevant levels of ethanol substantially impaired migration of cerebellar neurons by attenuating intracellular $\mathrm{Ca}^{2+}$ signals (Kumada et al., 2006). In contrast, exposure to relatively low levels of ethanol in utero elevated ambient GABA level, enhanced the sensitivity of MGE-derived interneurons to GABA and promoted premature tangential migration into the cortical anlage (Cuzon et al., 2008). A direct link between neuronal migration disorders and glutamate receptor dysfunction has been found in a mouse model for Zellweger disease. Here the migration defect results from a mutation in the NMDA receptor mediated $\mathrm{Ca}^{2+}$ mobilization (Gressens et al., 2000).

In summary, exposure of the prenatal human brain to drugs and pharmacological agents acting on glutamate and/or GABA receptors, may have a profound influence on tangential and radial migration. The resulting neuronal migration disorders may be difficult to detect and may result in therapy-resistant neurological and neuropsychiatric disorders.

\section{OPEN OUESTIONS AND CONCLUSIONS}

Although the last two decades provided a large amount of experimental data on the role of glutamate and GABA on neuronal migration in the cerebral cortex, a number of questions need to be addressed in order to understand the function of these two classical neurotransmitters and other transmitters in more detail.

1. What is the function of different receptor subunits in neuronal migration? It became recently clear that migrating neurons change during the migration process the expression of their functional receptors, receptor subtypes and subunits. However, the exact role of these developmental changes on the migration process is largely unknown.

2. What are the physiological extracellular concentrations of glutamate, GABA, taurine and glycine in distinct brain regions (e.g., cortical layers) and at different developmental periods? The answer to this question will provide important information to understand tangential and radial migration patterns.

3. What are the roles of other transmitter system beside glutamate and GABA? There are a few reports that other classical neurotransmitters like dopamine or serotonin are also implicated in the control of neuronal migration (e.g., Crandall et al., 2007; Riccio et al., 2011). However, a detailed analysis of the mechanisms of their actions or the identification of other neurotransmitters affecting migration remains open.

4. Which neuronal migration patterns are physiological and which ones are pathophysiological? This question is of major clinical relevance and may be difficult to answer with in vitro approaches, where experimental conditions are more or less artificial.

5. When and how does a neuronal migration disorder result in a clinical manifestation of a neurological or neuropsychiatric disease? This is another clinically relevant question and addresses the problem that small structural alterations due to migration disorders may be difficult to detect with conventional imaging techniques.

6. At which time points are the different migration processes respond most sensitive to noxious stimuli? Drugs, hypoxia, inflammation and other noxious conditions in the prenatal brain probably influence the different types and modes of migration in a time-dependent manner. E.g., it is unclear in which developmental period of the prenatal human brain certain drugs have strong impact on radial or tangential migration.

7. What are the (epi-)genetic causes of neuronal migration disorders? Although this field strongly developed over the last decade (for review, LoTurco and Bai, 2006; Guerrini and Parrini, 2010), the influence of genetic and epigenetic factors in distinct migration processes is often still not known.

8. What are the migratory pathways and mechanisms in primates? The vast majority of information on neuronal migration comes from experimental studies on rodents. However, some early events in neocortical development are different between rodents and primates (for review Rakic, 2009). A better understanding of neuronal migration and 
migration disorders in humans, may require further studies in primates.

In summary, a variety of studies provide substantial evidence that the classical neurotransmitters GABA and glutamate influence neuronal migration and may thus directly contribute to the pathogenesis of neuronal migration disorders. However, the effects of these neurotransmitters are not uniform, but depend on the brain region, identity and maturational state of the migrating neuron and the neurotransmitter receptor subtypes involved. Awareness of the complex interplay between neurotransmitter action and cellular migration processes may help to prevent migration disorders during fetal development.

\section{ACKNOWLEDGMENTS}

We thank our colleagues who contributed to the work reviewed in this paper. This work was supported by the Deutsche Forschungsgemeinschaft (SFB 1080 and KI835/2).

\section{REFERENCES}

Allene, C., and Cossart, R. (2010). Early NMDA receptor-driven waves of activity in the developing neocortex: physiological or pathological network oscillations? J. Physiol. 588, 83-91. doi: 10.1113/jphysiol.2009.178798

Avila, A., Vidal, P. M., Dear, T. N., Harvey, R. J., Rigo, J. M., and Nguyen, L. (2013). Glycine receptor alpha 2 subunit activation promotes cortical interneuron migration. Cell Rep. 4, 738-750. doi: 10.1016/j.celrep.2013.07.016

Ayala, R., Shu, T., and Tsai, L. H. (2007). Trekking across the brain: the journey of neuronal migration. Cell 128, 29-43. doi: 10.1016/j.cell.2006.12.021

Bagnard, D., Vaillant, C., Khuth, S. T., Dufay, N., Lohrum, M., Püschel, A. W., et al. (2001). Semaphorin 3A-vascular endothelial growth factor-165 balance mediates migration and apoptosis of neural progenitor cells by the recruitment of shared receptor. J. Neurosci. 21, 3332-3341.

Bahn, S., Volk, B., and Wisden, W. (1994). Kainate receptor gene expression in the developing rat brain. J. Neurosci. 14, 5525-5547.

Behar, T. N., Li, Y. X., Tran, H. T., Ma, W., Dunlap, V., Scott, C., et al. (1996). GABA stimulates chemotaxis and chemokinesis of embryonic cortical neurons via calcium-dependent mechanisms. J. Neurosci. 16, 1808-1818.

Behar, T. N., Schaffner, A. E., Scott, C. A., Greene, C. L., and Barker, J. L. (2000). GABA receptor antagonists modulate postmitotic cell migration in slice cultures of embryonic rat cortex. Cereb. Cortex 10, 899-909. doi: 10.1093/cercor/10.9.899

Behar, T. N., Schaffner, A. E., Scott, C. A., O'Connell, C., and Barker, J. L. (1998). Differential response of cortical plate and ventricular zone cells to GABA as a migration stimulus. J. Neurosci. 18, 6378-6387.

Behar, T. N., Scott, C. A., Greene, C. L., Wen, X. L., Smith, S. V., Maric, D., et al. (1999). Glutamate acting at NMDA receptors stimulates embryonic cortical neuronal migration. J. Neurosci. 19, 4449-4461.

Behar, T. N., Smith, S. V., Kennedy, R. T., Mckenzie, J. M., Maric, I., and Barker, A. L. (2001). GABAB receptors mediate motility signals for migrating embryonic cortical cells. Cereb. Cortex 11, 744-753. doi: 10.1093/cercor/11.8.744

Ben-Ari, Y., Gaiarsa, J. L., Tyzio, R., and Khazipov, R. (2007). GABA: a pioneer transmitter that excites immature neurons and generates primitive oscillations. Physiol. Rev. 87, 1215-1284. doi: 10.1152/physrev.00017.2006

Bolteus, A. J., Garganta, C., and Bordey, A. (2005). Assays for measuring extracellular GABA levels and cell migration rate in acute slices. Brain Res. Brain Res. Protoc. 14, 126-134. doi: 10.1016/j.brainresprot.2004.12.005

Bony, G., Szczurkowska, J., Tamagno, I., Shelly, M., Contestabile, A., and Cancedda, L. (2013). Non-hyperpolarizing GABA(B) receptor activation regulates neuronal migration and neurite growth and specification by cAMP/LKB1. Nat. Commun. 4:1800. doi: 10.1038/ncomms 2820

Borrell, V., and Marín, O. (2006). Meninges control tangential migration of hemderived Cajal-Retzius cells via CXCL12/CXCR4 signaling. Nat. Neurosci. 9, 1284-1293. doi: 10.1038/nn1764

Bortone, D., and Polleux, F. (2009). KCC2 expression promotes the termination of cortical interneuron migration in a voltage-sensitive calcium-dependent manner. Neuron 62, 53-71. doi: 10.1016/j.neuron.2009.01.034
Butt, S. J. B., Cobos, I., Golden, J., Kessaris, N., Pachnis, V., and Anderson, S. (2007) Transcriptional regulation of cortical interneuron development. J.Neurosci. 27, 11847-11850. doi: 10.1523/jneurosci.3525-07.2007

Butt, S. J., Fuccillo, M., Nery, S., Noctor, S., Kriegstein, A., Corbin, J. G., et al. (2005). The temporal and spatial origins of cortical interneurons predict their physiological subtype. Neuron 48, 591-604. doi: 10.1016/j.neuron.2005.09.034

Bystron, I., Blakemore, C., and Rakic, P. (2008). Development of the human cerebral cortex: Boulder committee revisited. Nat. Rev. Neurosci. 9, 110-122. doi: $10.1038 / \mathrm{nrn} 2252$

Cancedda, L., Fiumelli, H., Chen, K., and Poo, M. M. (2007). Excitatory GABA action is essential for morphological maturation of cortical neurons in vivo. J. Neurosci. 27, 5224-5235. doi: 10.1523/jneurosci.5169-06.2007

Carlson, V. C. C., and Yeh, H. H. (2011). GABA(A) receptor subunit profiles of tangentially migrating neurons derived from the medial ganglionic eminence. Cereb. Cortex 21, 1792-1802. doi: 10.1093/cercor/bhq247

Chandrasekar, R. (2013). Alcohol and NMDA receptor: current research and future direction. Front. Mol. Neurosci. 6:14. doi: 10.3389/fnmol.2013.00014

Cina, C., Maass, K., Theis, M., Willecke, K., Bechberger, J. F., and Naus, C. C. (2009). Involvement of the cytoplasmic C-terminal domain of connexin43 in neuronal migration. J. Neurosci. 29, 2009-2021. doi: 10.1523/jneurosci.5025-08.2009

Cooper, J. A. (2008). A mechanism for inside-out lamination in the neocortex. Trends Neurosci. 31, 113-119. doi: 10.1016/j.tins.2007.12.003

Crandall, J. E., McCarthy, D. M., Araki, K. Y., Sims, J. R., Ren, J.-Q., and Bhide, P. G. (2007). Dopamine receptor activation modulates GABA neuron migration from the basal forebrain to the cerebral cortex. J. Neurosci. 27, 3813-3822. doi: 10. 1523/jneurosci.5124-06.2007

Cuzon, V. C., Yeh, P. W., Cheng, Q., and Yeh, H. H. (2006). Ambient GABA promotes cortical entry of tangentially migrating cells derived from the medial ganglionic eminence. Cereb. Cortex 16, 1377-1388. doi: 10.1093/cercor/bhj084

Cuzon, V. C., Yeh, P. W., Yanagawa, Y., Obata, K., and Yeh, H. H. (2008). Ethanol consumption during early pregnancy alters the disposition of tangentially migrating GABAergic interneurons in the fetal cortex. J. Neurosci. 28, 1854 1864. doi: 10.1523/jneurosci.5110-07.2008

de Carlos, J. A., Lopez-Mascaraque, L., and Valverde, F. (1996). Dynamics of cell migration from the lateral ganglionic eminence in the rat. J. Neurosci. 16, 61466156.

de Lima, A. D., Gieseler, A., and Voigt, T. (2009). Relationship between GABAergic interneurons migration and early neocortical network activity. Dev. Neurobiol. 69, 105-123. doi: 10.1002/dneu.20696

Denter, D. G., Heck, N., Riedemann, T., White, R., Kilb, W., and Luhmann, H. J. (2010). GABA(C) receptors are functionally expressed in the intermediate zone and regulate radial migration in the embryonic mouse neocortex. Neuroscience 167, 124-134. doi: 10.1016/j.neuroscience.2010.01.049

Dvorzhak, A., Myakhar, O., Unichenko, P., Kirmse, K., and Kirischuk, S. (2010). Estimation of ambient GABA levels in layer I of the mouse neonatal cortex in brain slices. J. Physiol. 588, 2351-2360. doi: 10.1113/jphysiol.2010. 187054

Elias, L. A., and Kriegstein, A. R. (2008). Gap junctions: multifaceted regulators of embryonic cortical development. Trends Neurosci. 31, 243-250. doi: 10.1016/j. tins.2008.02.007

Elias, L. A., Turmaine, M., Parnavelas, J. G., and Kriegstein, A. R. (2010). Connexin 43 mediates the tangential to radial migratory switch in ventrally derived cortical interneurons. J. Neurosci. 30, 7072-7077. doi: 10.1523/jneurosci.5728-09. 2010

Elias, L. A., Wang, D. D., and Kriegstein, A. R. (2007). Gap junction adhesion is necessary for radial migration in the neocortex. Nature 448, 901-907. doi: 10 . 1038/nature06063

Fahrion, J. K., Komuro, Y., Li, Y., Ohno, N., Littner, Y., Raoult, E., et al. (2012). Rescue of neuronal migration deficits in a mouse model of fetal Minamata disease by increasing neuronal Ca2+ spike frequency. Proc. Natl. Acad. Sci. US A 109, 5057-5062. doi: 10.1073/pnas.1120747109

Farrant, M., and Kaila, K. (2007). The cellular, molecular and ionic basis of GABA(A) receptor signalling. Prog. Brain Res. 160, 59-87. doi: 10.1016/s00796123(06)60005-8

Flint, A. C., Liu, X. L., and Kriegstein, A. R. (1998). Nonsynaptic glycine receptor activation during early neocortical development. Neuron 20, 43-53. doi: 10. 1016/s0896-6273(00)80433-x

Friocourt, G., Liu, J. S., Antypa, M., Rakic, S., Walsh, C. A., and Parnavelas, J. G. (2007). Both doublecortin and doublecortin-like kinase play a role in cortical 
interneuron migration. J. Neurosci. 27, 3875-3883. doi: 10.1523/jneurosci.453006.2007

Furukawa, T., Yamada, J., Akita, T., Matsushima, Y., Yanagawa, Y., and Fukuda, A. (2014). Roles of taurine-mediated tonic GABAA receptor activation in the radial migration of neurons in the fetal mouse cerebral cortex. Front. Cell. Neurosci. 8:88. doi: $10.3389 /$ fncel.2014.00088

Gelman, D. M., and Marin, O. (2010). Generation of interneuron diversity in the mouse cerebral cortex. Eur. J. Neurosci. 31, 2136-2141. doi: 10.1111/j.1460-9568. 2010.07267.x

Gerber, A. M., Beaman-Hall, C. M., Mathur, A., and Vallano, M. L. (2010). Reduced blockade by extracellular $\mathrm{Mg} 2+$ is permissive to NMDA receptor activation in cerebellar granule neurons that model a migratory phenotype. J. Neurochem. 114, 191-202. doi: 10.1111/j.1471-4159.2010.06746.x

Gleeson, J. G., and Walsh, C. A. (2000). Neuronal migration disorders: from genetic diseases to developmental mechanisms. Trends Neurosci. 23, 352-359. doi: 10. 1016/s0166-2236(00)01607-6

Gressens, P., Baes, M., Leroux, P., Lombet, A., Van Veldhoven, P., Janssen, A., et al. (2000). Neuronal migration disorder in Zellweger mice is secondary to glutamate receptor dysfunction. Ann. Neurol. 48, 336-343. doi: 10.1002/15318249(200009)48:3<336::aid-ana8>3.0.co;2-q

Guerrini, R., Dobyns, W. B., and Barkovich, A. J. (2008). Abnormal development of the human cerebral cortex: genetics, functional consequences and treatment options. Trends Neurosci. 31, 154-162. doi: 10.1016/j.tins.2007.12.004

Guerrini, R., and Parrini, E. (2010). Neuronal migration disorders. Neurobiol. Dis. 38, 154-166. doi: 10.1016/j.nbd.2009.02.008

Heck, N., Kilb, W., Reiprich, P., Kubota, H., Furukawa, T., Fukuda, A., et al. (2007). GABA-A receptors regulate neocortical neuronal migration in vitro and in vivo. Cereb. Cortex 17, 138-148. doi: 10.1093/cercor/bhj135

Hirai, K., Yoshioka, H., Kihara, M., Hasegawa, K., Sakamoto, T., Sawada, T., et al. (1999). Inhibiting neuronal migration by blocking NMDA receptors in the embryonic rat cerebral cortex: a tissue culture study. Brain Res. Dev. Brain Res. 114, 63-67. doi: 10.1016/s0165-3806(99)00019-x

Holmberg, J., Genander, M., Halford, M. M., Annerén, C., Sondell, M., Chumley, M. J., et al. (2006). EphB receptors coordinate migration and proliferation in the intestinal stem cell niche. Cell 125, 1151-1163. doi: 10.1016/j.cell.2006. 04.030

Huang, Z. (2009). Molecular regulation of neuronal migration during neocortical development. Mol. Cell. Neurosci. 42, 11-22. doi: 10.1016/j.mcn.2009.06.003

Ikonomidou, C., and Turski, L. (2010). Antiepileptic drugs and brain development. Epilepsy Res. 88, 11-22. doi: 10.1016/j.eplepsyres.2009.09.019

Inada, H., Watanabe, M., Uchida, T., Ishibashi, H., Wake, H., Nemoto, T., et al. (2011). GABA regulates the multidirectional tangential migration of GABAergic interneurons in living neonatal mice. Plos One 6:e27048. doi: 10.1371/journal. pone. 0027048

Inoue, K., Furukawa, T., Kumada, T., Yamada, J., Wang, T. Y., Inoue, R., et al. (2012). Taurine inhibits K+-Cl- cotransporter KCC2 to regulate embryonic Cl- homeostasis via With-no-lysine (WNK) protein kinase signaling pathway. J. Biol. Chem. 287, 20839-20850. doi: 10.1074/jbc.m111.319418

Inta, D., Alfonso, J., von Engelhardt, J., Kreuzberg, M. M., Meyer, A. H., van Hooft, J. A., et al. (2008). Neurogenesis and widespread forebrain migration of distinct GABAergic neurons from the postnatal subventricular zone. Proc. Natl. Acad. Sci. US A 105, 20994-20999. doi: 10.1073/pnas.0807059105

Iwasato, T., Datwani, A., Wolf, A. M., Nishiyama, H., Taguchi, Y., Tonegawa, S., et al. (2000). Cortex-restricted disruption of NMDAR1 impairs neuronal patterns in the barrel cortex. Nature 406, 726-731. doi: 10.1038/35021059

Jansson, L. C., Louhivuori, L., Wigren, H. K., Nordström, T., Louhivuori, V., Castrén, M. L., et al. (2013). Effect of glutamate receptor antagonists on migrating neural progenitor cells. Eur. J. Neurosci. 37, 1369-1382. doi: 10. 1111/ejn.12152

Ji, F. Y., Kanbara, N., and Obata, K. (1999). GABA and histogenesis in fetal and neonatal mouse brain lacking both the isoforms of glutamic acid decarboxylase. Neurosci. Res. 33, 187-194. doi: 10.1016/s0168-0102(99)00011-5

Jovanovic, J. N., and Thomson, A. M. (2011). Development of cortical GABAergic innervation. Front. Cell. Neurosci. 5:14. doi: 10.3389/fncel.2011.00014

Kaila, K. (2014). Cation-chloride cotransporters in neuronal development, plasticity and disease. Nat. Rev. Neurosci. 15, 637-654. doi: 10.1038/nrn3819

Khazipov, R., and Luhmann, H. J. (2006). Early patterns of electrical activity in the developing cerebral cortex of human and rodents. Trends Neurosci. 29, 414-418. doi: 10.1016/j.tins.2006.05.007
Kholmanskikh, S. S., Koeller, H. B., Wynshaw-Boris, A., Gomez, T., Letourneau, P. C., and Ross, M. E. (2006). Calcium-dependent interaction of lis 1 with IQGAP1 and Cdc42 promotes neuronal motility. Nat. Neurosci. 9, 50-57. doi: $10.1038 / \mathrm{nn} 1619$

Kihara, M., Yoshioka, H., Hirai, K., Hasegawa, K., Kizaki, Z., and Sawada, T. (2002). Stimulation of N-methyl-D-aspartate (NMDA) receptors inhibits neuronal migration in embryonic cerebral cortex: a tissue culture study. Brain Res. Dev. Brain Res. 138, 195-198. doi: 10.1016/s0165-3806(02)00490-x

Kilb, W. (2012). Development of the GABAergic system from birth to adolescence. Neuroscientist 18, 613-630. doi: 10.1177/1073858411422114

Kilb, W., Hanganu, I. L., Okabe, A., Sava, B. A., Shimizu-Okabe, C., Fukuda, A., et al. (2008). Glycine receptors mediate excitation of subplate neurons in neonatal rat cerebral cortex. J. Neurophysiol. 100, 698-707. doi: 10.1152/jn. 00657.2007

Kilb, W., Ikeda, M., Uchida, K., Okabe, A., Fukuda, A., and Luhmann, H. J. (2002). Depolarizing glycine responses in Cajal-Retzius cells of neonatal rat cerebral cortex. Neuroscience 112, 299-307. doi: 10.1016/s0306-4522(02)00071-4

Kilb, W., Kirischuk, S., and Luhmann, H. J. (2011). Electrical activity patterns and the functional maturation of the neocortex. Eur. J. Neurosci. 34, 1677-1686. doi: 10.1111/j.1460-9568.2011.07878.x

Kilb, W., Kirischuk, S., and Luhmann, H. J. (2013). Role of tonic GABAergic currents during pre- and early postnatal rodent development. Front. Neural Circuits 7:139. doi: 10.3389/fncir.2013.00139

Kim, P. M., Aizawa, H., Kim, P. S., Huang, A. S., Wickramasinghe, S. R., Kashani, A. H., et al. (2005). Serine racemase: activation by glutamate neurotransmission via glutamate receptor interacting protein and mediation of neuronal migration. Proc. Natl. Acad. Sci. U S A 102, 2105-2110. doi: 10.1073/pnas.0409723102

Kirischuk, S., and Kilb, W. (2012). "GAT (GABA transporters)," in Encyclopedia of Signaling Molecules, ed C. Sangdun (New York: Springer), 756-760.

Kirischuk, S., Luhmann, H. J., and Kilb, W. (2014). Cajal-Retzius cells: update on structural and functional properties of these mystic neurons that bridged the 20th century. Neuroscience 275, 33-46. doi: 10.1016/j.neuroscience.2014.06.009

Koizumi, H., Tanaka, T., and Gleeson, J. G. (2006). Doublecortin-like kinase functions with doublecortin to mediate fiber tract decussation and neuronal migration. Neuron 49, 55-66. doi: 10.1016/j.neuron.2005.10.040

Kojima, T., Hirota, Y., Ema, M., Takahashi, S., Miyoshi, I., Okano, H., et al. (2010). Subventricular zone-derived neural progenitor cells migrate along a blood vessel scaffold toward the post-stroke striatum. Stem Cells 28, 545-554. doi: 10.1002/stem.306

Komuro, H., and Kumada, T. (2005). Ca2+ transients control CNS neuronal migration. Cell Calcium 37, 387-393. doi: 10.1016/j.ceca.2005.01.006

Komuro, H., and Rakic, P. (1993). Modulation of neuronal migration by NMDA receptors. Science 260, 95-97. doi: 10.1126/science.8096653

Komuro, H., and Rakic, P. (1996). Intracellular $\mathrm{Ca}^{2+}$ fluctuations modulate the rate of neuronal migration. Neuron 17, 275-285. doi: 10.1016/s0896-6273(00) 80159-2

Koyama, R., Tao, K., Sasaki, T., Ichikawa, J., Miyamoto, D., Muramatsu, R., et al. (2012). GABAergic excitation after febrile seizures induces ectopic granule cells and adult epilepsy. Nat. Med. 18, 1271-1278. doi: 10.1038/nm.2850

Kumada, T., and Komuro, H. (2004). Completion of neuronal migration regulated by loss of $\mathrm{Ca}(2+)$ transients. Proc. Natl. Acad. Sci. US A 101, 8479-8484. doi: 10. 1073/pnas.0401000101

Kumada, T., Lakshmana, M. K., and Komuro, H. (2006). Reversal of neuronal migration in a mouse model of fetal alcohol syndrome by controlling secondmessenger signalings. J. Neurosci. 26, 742-756. doi: 10.1523/jneurosci.4478-05. 2006

Kwan, K. Y., Sestan, N., and Anton, E. S. (2012). Transcriptional co-regulation of neuronal migration and laminar identity in the neocortex. Development 139, 1535-1546. doi: 10.1242/dev.069963

Laurie, D. J., Wisden, W., and Seeburg, P. H. (1992). The distribution of thirteen $\mathrm{GABA}_{\mathrm{A}}$ receptor subunit mRNAs in the rat brain. III. Embryonic and postnatal development. J. Neurosci. 12, 4151-4172.

Lee, S., Yoon, B. E., Berglund, K., Oh, S. J., Park, H., Shin, H. S., et al. (2010). Channel-Mediated tonic GABA release from Glia. Science 330, 790-796. doi: 10. 1126/science. 1184334

Le Magueresse, C., Alfonso, J., Bark, C., Eliava, M., Khrulev, S., and Monyer, H. (2012). Subventricular zone-derived neuroblasts use vasculature as a scaffold to migrate radially to the cortex in neonatal mice. Cereb. Cortex 22, 2285-2296. doi: $10.1093 /$ cercor/bhr302 
Letinic, K., Zoncu, R., and Rakic, P. (2002). Origin of GABAergic neurons in the human neocortex. Nature 417, 645-649. doi: 10.1038/nature00779

Lobo, I. A., and Harris, R. A. (2008). GABA-A receptors and alcohol. Pharmacol. Biochem. Behav. 90, 90-94. doi: 10.1016/j.pbb.2008.03.006

López-Bendito, G., Luján, R., Shigemoto, R., Ganter, P., Paulsen, O., and Molnár, Z. (2003). Blockade of GABA-B receptors alters the tangential migration of cortical neurons. Cereb. Cortex 13, 932-942. doi: 10.1093/cercor/13.9.932

López-Bendito, G., Shigemoto, R., Fairén, A., and Luján, R. (2002a). Differential distribution of group I metabotropic glutamate receptors during rat cortical development. Cereb. Cortex 12, 625-638. doi: 10.1093/cercor/12.6.625

López-Bendito, G., Shigemoto, R., Kulik, A., Paulsen, O., Fairén, A., and Luján, R. (2002b). Expression and distribution of metabotropic GABA receptor subtypes GABA-BR1 and GABA-BR2 during rat neocortical development. Eur. J. Neurosci. 15, 1766-1778. doi: 10.1046/j.1460-9568.2002. 02032.x

LoTurco, J. J., and Bai, J. (2006). The multipolar stage and disruptions in neuronal migration. Trends Neurosci. 29, 407-413. doi: 10.1016/j.tins.2006. 05.006

LoTurco, J. J., Owens, D. F., Heath, M. J. S., Davis, M. B. E., and Kriegstein, A. R. (1995). GABA and glutamate depolarize cortical progenitor cells and inhibit DNA synthesis. Neuron 15, 1287-1298. doi: 10.1016/0896-6273(95) 90008-x

Luhmann, H. J., Kirischuk, S., Sinning, A., and Kilb, W. (2014). Early GABAergic circuitry in the cerebral cortex. Curr. Opin. Neurobiol. 26, 72-78. doi: 10.1016/j. conb.2013.12.014

Luján, R., Shigemoto, R., and López-Bendito, G. (2005). Glutamate and GABA receptor signalling in the developing brain. Neuroscience 130, 567-580. doi: 10. 1016/j.neuroscience.2004.09.042

Ma, T., Wang, C. M., Wang, L., Zhou, X., Tian, M., Zhang, Q. Q., et al. (2013). Subcortical origins of human and monkey neocortical interneurons. Nat. Neurosci. 16, 1588-1597. doi: 10.1038/nn.3536

Mancini, J. D., and Atchison, W. D. (2007). The NR2B subunit in NMDA receptors is functionally important during cerebellar granule cell migration. Neurosci. Lett. 429, 87-90. doi: 10.1016/j.neulet.2007.09.079

Manent, J. B., Beguin, S., Ganay, T., and Represa, A. (2011). Cell-autonomous and cell-to-cell signalling events in normal and altered neuronal migration. Eur. J. Neurosci. 34, 1595-1608. doi: 10.1111/j.1460-9568.2011.07867.x

Manent, J. B., Demarque, M., Jorquera, I., Pellegrino, C., Ben-Ari, Y., Aniksztejn, L., et al. (2005). A noncanonical release of GABA and glutamate modulates neuronal migration. J. Neurosci. 25, 4755-4765. doi: 10.1523/jneurosci.0553-05. 2005

Manent, J. B., Jorquera, I., Ben-Ari, Y., Aniksztejn, L., and Represa, A. (2006). Glutamate acting on AMPA but not NMDA receptors modulates the migration of hippocampal interneurons. J. Neurosci. 26, 5901-5909. doi: 10. 1523/jneurosci.1033-06.2006

Manent, J. B., Jorquera, I., Mazzucchelli, I., Depaulis, A., Perucca, E., Ben-Ari, Y., et al. (2007). Fetal exposure to GABA-acting antiepileptic drugs generates hippocampal and cortical dysplasias. Epilepsia 48, 684-693. doi: 10.1111/j.15281167.2007.01056.x

Manent, J. B., and Represa, A. (2007). Neurotransmitters and brain maturation: early paracrine actions of GABA and glutamate modulate neuronal migration. Neuroscientist 13, 268-279. doi: 10.1177/1073858406298918

Marín, O. (2013). Cellular and molecular mechanisms controlling the migration of neocortical interneurons. Eur. J. Neurosci. 38, 2019-2029. doi: 10.1111/ejn. 12225

Marret, S., Gressens, P., and Evrard, P. (1996). Arrest of neuronal migration by excitatory amino acids in hamster developing brain. Proc. Natl. Acad. Sci. U S A 93, 15463-15468. doi: 10.1073/pnas.93.26.15463

Maskos, U., and McKay, R. D. G. (2003). Neural cells without functional N-methyl$\mathrm{D}$-aspartate (NMDA) receptors contribute extensively to normal postnatal brain development in efficiently generated chimaeric NMDA R1-/-<->+/+ mice. Dev. Biol. 262, 119-136. doi: 10.1016/s0012-1606(03)00354-3

Messersmith, E. K., Feller, M. B., Zhang, H., and Shatz, C. J. (1997). Migration of neocortical neurons in the absence of functional NMDA receptors. Mol. Cell. Neurosci. 9, 347-357. doi: 10.1006/mcne.1997.0646

Miller, M. W. (1992). "Effects of prenatal exposure to ethanol on cell proliferation and neuronal migration," in Development of the Centarl Nervous System, ed M. W. Miller (New York, Chichester, Brisbane, Toronto, Singapore: John Wiley and Sons, Inc.), 47-69.
Morishima, T., Uematsu, M., Furukawa, T., Yanagawa, Y., Fukuda, A., and Yoshida, S. (2010). GABA imaging in brain slices using immobilized enzyme-linked photoanalysis. Neurosci. Res. 67, 347-353. doi: 10.1016/j.neures.2010.04.005

Moya, F., and Valdeolmillos, M. (2004). Polarized increase of calcium and nucleokinesis in tangentially migrating neurons. Cereb. Cortex 14, 610-618. doi: 10.1093/cercor/bhh022

Nadarajah, B., Alifragis, P., Wong, R. O. L., and Parnavelas, J. G. (2003). Neuronal migration in the developing cerebral cortex: observations based on real-time imaging. Cereb. Cortex 13, 607-611. doi: 10.1093/cercor/13.6.607

Nimmervoll, B., Denter, D. G., Sava, I., Kilb, W., and Luhmann, H. J. (2011). Glycine receptors influence radial migration in the embryonic mouse neocortex. Neuroreport 22, 509-513. doi: 10.1097/wnr.0b013e328348aafe

Noctor, S. C., Flint, A. C., Weissman, T. A., Dammerman, R. S., and Kriegstein, A. R. (2001). Neurons derived from radial glial cells establish radial units in neocortex. Nature 409, 714-720. doi: 10.1038/35055553

Noctor, S. C., Martínez-Cerdeño, V., Ivic, L., and Kriegstein, A. R. (2004). Cortical neurons arise in symmetric and asymmetric division zones and migrate through specific phases. Nat. Neurosci. 7, 136-144. doi: 10.1038/nn1172

Okabe, A., Kilb, W., Shimizu-Okabe, C., Hanganu, I. L., Fukuda, A., and Luhmann, H. J. (2004). Homogenous glycine receptor expression in cortical plate neurons and Cajal-Retzius cells of neonatal rat cerebral cortex. Neuroscience 123, 715724. doi: 10.1016/j.neuroscience.2003.10.014

Owens, D. F., Liu, X. L., and Kriegstein, A. R. (1999). Changing properties of $\mathrm{GABA}_{\mathrm{A}}$ receptor-mediated signaling during early neocortical development. J. Neurophysiol. 82, 570-583.

Pla, R., Borrell, V., Flames, N., and Marin, O. (2006). Layer acquisition by cortical GABAergic interneurons is independent of Reelin signaling. J. Neurosci. 26, 6924-6934. doi: 10.1523/jneurosci.0245-06.2006

Poluch, S., and König, N. (2002). AMPA receptor activation induces GABA release from neurons migrating tangentially in the intermediate zone of embryonic rat neocortex. Eur. J. Neurosci. 16, 350-354. doi: 10.1046/j.1460-9568.2002. 02068.x

Qian, T. Z., Chen, R. Q., Nakamura, M., Furukawa, T., Kumada, T., Akita, T., et al. (2014). Activity-dependent endogenous taurine release facilitates excitatory neurotransmission in the neocortical marginal zone of neonatal rats. Front. Cell. Neurosci. 8:33. doi: 10.3389/fncel.2014.00033

Rakic, P. (1972). Mode of cell migration to the superficial layers of fetal monkey neocortex. J. Comp. Neurol. 145, 61-83. doi: 10.1002/cne.901450105

Rakic, P. (2009). Evolution of the neocortex: a perspective from developmental biology. Nat. Rev. Neurosci. 10, 724-735. doi: 10.1038/nrn2719

Reiprich, P., Kilb, W., and Luhmann, H. J. (2005). Neonatal NMDA receptor blockade disturbs neuronal migration in rat somatosensory cortex in vivo. Cereb. Cortex 15, 349-358. doi: 10.1093/cercor/bhh137

Riccio, O., Jacobshagen, M., Golding, B., Vutskits, L., Jabaudon, D., Hornung, J.P., et al. (2011). Excess of serotonin affects neocortical pyramidal neuron migration. Transl. Psychiat. 1:e47. doi: 10.1038/tp.2011.49

Sentürk, A., Pfennig, S., Weiss, A., Burk, K., and Acker-Palmer, A. (2011). Ephrin Bs are essential components of the Reelin pathway to regulate neuronal migration. Nature 472, 356-360. doi: 10.1038/nature09874

Smith, A. L., Cordery, P. M., and Thompson, I. D. (1995). Manufacture and release characteristics of Elvax polymers containing glutamate receptor antagonists. J. Neurosci. Methods 60, 211-217. doi: 10.1016/0165-0270(95)00014-1

Soria, J. M., and Valdeolmillos, M. (2002). Receptor-activated calcium signals in tangentially migrating cortical cells. Cereb. Cortex 12, 831-839. doi: 10. 1093/cercor/12.8.831

Syková, E. (2004). Extrasynaptic volume transmission and diffusion parameters of the extracellular space. Neuroscience 129, 861-876. doi: 10.1016/j.neuroscience. 2004.06.077

Takano, T., Sawai, C., and Takeuchi, Y. (2004). Radial and tangential neuronal migration disorder in ibotenate-induced cortical lesions in hamsters: immunohistochemical study of reelin, vimentin and calretinin. J. Child Neurol. 19, 107-115. doi: 10.1177/08830738040190020501

Tanaka, D. H., and Nakajima, K. (2012). Migratory pathways of GABAergic interneurons when they enter the neocortex. Eur. J. Neurosci. 35, 1655-1660. doi: 10.1111/j.1460-9568.2012.08111.x

Tanaka, D., Nakaya, Y., Yanagawa, Y., Obata, K., and Murakami, F. (2003). Multimodal tangential migration of neocortical GABAergic neurons independent of GPI-anchored proteins. Development 130, 5803-5813. doi: 10. $1242 /$ dev. 00825 
Tanaka, D. H., Yanagida, M., Zhu, Y., Mikami, S., Nagasawa, T., Miyazaki, J., et al. (2009). Random walk behavior of migrating cortical interneurons in the marginal zone: time-lapse analysis in flat-mount cortex. J. Neurosci. 29, 13001311. doi: 10.1523/jneurosci.5446-08.2009

Tárnok, K., Czöndör, K., Jelitai, M., Czirók, A., and Schlett, K. (2008). NMDA receptor NR2B subunit over-expression increases cerebellar granule cell migratory activity. J. Neurochem. 104, 818-829. doi: 10.1111/j.14714159.2007.0501.x

Teissier, A., Griveau, A., Vigier, L., Piolot, T., Borello, U., and Pierani, A. (2010). A novel transient glutamatergic population migrating from the pallial-subpallial boundary contributes to neocortical development. J. Neurosci. 30, 10563-10574. doi: 10.1523/jneurosci.0776-10.2010

Thomas, C. G., Tian, H., and Diamond, J. S. (2011). The relative roles of diffusion and uptake in clearing synaptically released glutamate change during early postnatal development. J. Neurosci. 31, 4743-4754. doi: 10.1523/jneurosci.595310.2011

Ulrich, D., and Bettler, B. (2007). GABA(B) receptors: synaptic functions and mechanisms of diversity. Curr. Opin. Neurobiol. 17, 298-303. doi: 10.1016/j. conb.2007.04.001

Unichenko, P., Dvorzhak, A., and Kirischuk, S. (2013). Transporter-mediated replacement of extracellular glutamate for GABA in the developing murine neocortex. Eur. J. Neurosci. 38, 3580-3588. doi: 10.1111/ejn.12380

Valiente, M., and Marín, O. (2010). Neuronal migration mechanisms in development and disease. Curr. Opin. Neurobiol. 20, 68-78. doi: 10.1016/j.conb. 2009.12.003

Wang, Y., Dye, C. A., Sohal, V., Long, J. E., Estrada, R. C., Roztocil, T., et al. (2010). Dlx5 and Dlx6 regulate the development of parvalbumin-expressing cortical interneurons. J. Neurosci. 30, 5334-5345. doi: 10.1523/jneurosci.5963-09.2010

Wang, T. Y., Kumada, T., Morishima, T., Iwata, S., Kaneko, T., Yanagawa, Y., et al. (2014). Accumulation of GABAergic Neurons, causing a focal ambient GABA gradient and downregulation of KCC2 are induced during microgyrus formation in a mouse model of polymicrogyria. Cereb. Cortex 24, 1088-1101. doi: $10.1093 /$ cercor/bhs375
Won, C., Lin, Z. C., Kumar, T. P., Li, S. Y., Ding, L., Elkhal, A., et al. (2013). Autonomous vascular networks synchronize GABA neuron migration in the embryonic forebrain. Nat. Comm. 4:2149. doi: 10.1038/ncomms 3149

Yamada, J., Okabe, A., Toyoda, H., Kilb, W., Luhmann, H. J., and Fukuda, A. (2004). Cl- uptake promoting depolarizing GABA actions in immature rat neocortical neurones is mediated by NKCC1. J. Physiol. 557, 829-841. doi: 10.1113/jphysiol. 2004.062471

Yu, Y. C., Bultje, R. S., Wang, X., and Shi, S. H. (2009). Specific synapses develop preferentially among sister excitatory neurons in the neocortex. Nature 458, 501-504. doi: 10.1038/nature07722

Zheng, J. Q., and Poo, M. M. (2007). Calcium signaling in neuronal motility. Annu. Rev. Cell Dev. Biol. 23, 375-404. doi: 10.1146/annurev.cellbio.23.090506.123221

Zimmer, G., Garcez, P., Rudolph, J., Niehage, R., Weth, F., Lent, R., et al. (2008). Ephrin-A5 acts as a repulsive cue for migrating cortical interneurons. Eur. J. Neurosci. 28, 62-73. doi: 10.1111/j.1460-9568.2008.06320.x

Conflict of Interest Statement: The authors declare that the research was conducted in the absence of any commercial or financial relationships that could be construed as a potential conflict of interest.

Received: 13 October 2014; accepted: 06 January 2015; published online: 30 January 2015.

Citation: Luhmann HJ, Fukuda A and Kilb W (2015) Control of cortical neuronal migration by glutamate and GABA. Front. Cell. Neurosci. 9:4. doi: $10.3389 /$ fncel.2015.00004

This article was submitted to the journal Frontiers in Cellular Neuroscience.

Copyright (c) 2015 Luhmann, Fukuda and Kilb. This is an open-access article distributed under the terms of the Creative Commons Attribution License (CC BY). The use, distribution and reproduction in other forums is permitted, provided the original author(s) or licensor are credited and that the original publication in this journal is cited, in accordance with accepted academic practice. No use, distribution or reproduction is permitted which does not comply with these terms. 